\title{
Psychiatric symptoms in adolescents: FKBP5 genotype-early life adversity interaction effects
}

\author{
Erika Comasco, Per Gustafsson, Gunilla Sydsjö, Sara Agnafors, \\ Nikolas Aho and Carl Göran Svedin
}

\section{Linköping University Post Print}

\section{Tweet}

N.B.: When citing this work, cite the original article.

The original publication is available at www.springerlink.com:

Erika Comasco, Per Gustafsson, Gunilla Sydsjö, Sara Agnafors, Nikolas Aho and Carl Göran Svedin, Psychiatric symptoms in adolescents: FKBP5 genotype-early life adversity interaction effects, 2015, European Child and Adolescent Psychiatry, (24), 12, 1473-1483.

http://dx.doi.org/10.1007/s00787-015-0768-3

Copyright: Springer Verlag (Germany)

http://www.springerlink.com/?MUD=MP

Postprint available at: Linköping University Electronic Press

http://urn.kb.se/resolve?urn=urn:nbn:se:liu:diva-123510 
Psychiatric Symptoms in Adolescents: FKBP5 Genotype - Early Life Adversity Interaction effects

Erika Comasco ${ }^{1 *}$, Per A Gustafsson ${ }^{2 *}$, Gunilla Sydsjö ${ }^{3}$, Sara Agnafors ${ }^{2}$, Nikolas Aho ${ }^{2}$, Carl Göran Svedin ${ }^{2}$

1. Department of Neuroscience, Uppsala University, Sweden

2. Division of Child and Adolescent Psychiatry, Linköping University, Sweden

3. Division of Obstetrics and Gynaecology, Linköping University, Sweden

\author{
* Correspondence: \\ Per A Gustafsson, Division of Child and Adolescent Psychiatry, IKE, Faculty of Health Sciences, Linköping \\ University, SE-581 85 Linköping, Sweden \\ Tel: +46-010-1032445; Fax: +46-13-143917 \\ Email: erika.comasco@neuro.uu.se; per.a.gustafsson@liu.se
}

Key-words: adolescents, fkbp5, gene, mental health, stress

\begin{abstract}
Psychiatric disorders are multi-factorial and their symptoms overlap. Constitutional and environmental factors influence each other, and this contributes to risk and resilience in mental ill-health. We investigated functional genetic variation of stress responsiveness, assessed as FKBP5 genotype, in relation to early life adversity and mental health in two samples of adolescents.

One population-based sample of 909 12-year-old adolescents (SESBiC) was assessed using the Life Incidence of Traumatic Events scale (LITE) and the Strengths and Difficulties Questionnaire (SDQ). One sample of 398 17year-old adolescents, enriched for poly-victimized individuals (USSS), was assessed using the Juvenile Victimization Questionnaire (JVQ) and the Trauma Symptom Checklist for Children (TSCC). The FKBP5 rs1360780 and rs3800373 polymorphisms were genotyped using a fluorescence-based competitive allele-specific PCR.
\end{abstract}

Most prominently among poly-victimized older male adolescents, the least common alleles of the polymorphisms, in interaction with adverse life events, were associated with psychiatric symptoms, after control of ethno-socio-economic factors. The interaction effect between rs3800373 and adverse life events on the TSCC sub-scales - anxiety, depression, anger, and dissociation - and with the rs1360780 on dissociation in the USSS cohort remained significant after Bonferroni correction.

This pattern of associationis in line with the findings of clinical and neuroimaging studies, and implies interactive effects of FKBP5 polymorphisms and early life environment on several psychiatric symptoms. These correlates add up to provide constructs that are relevant to several psychiatric symptoms, and to identify early predictors of mental ill-health. 


\section{Introduction}

Adolescence is a key developmental period: the brain is still developing, and pubertal changes together with typical behavioural traits and environmental cues can influence susceptibility to the development of psychopathology and related behavioural symptoms [1]. Furthering knowledge of the underlying pathological mechanisms of psychiatric symptoms at an early age is of considerable relevance for timely identification of individuals at risk who might benefit from targeted intervention [2].

Behavioural problems and psychiatric symptoms are more common among children who have been abused and neglected [3]. In Sweden, victimisation is common among adolescents with an average of 2.5 events of victimization during the previous year, and of 4.5 events as lifetime victimization measured at the age of seventeen [4]. However, not all children who are exposed to early life adversity develop psychiatric symptoms. Suggestive evidence has been provided of the interactive contribution of the psychosocial background and genetic makeup of the child to proneness to clinical and subclinical psychiatric symptoms during adolescence [5].

Concomitant to experimental findings on laboratory animals, human studies demonstrate that early life adversity has a strong impact on stress response, behaviour, and ultimately mental health. Stress response is a crucial link between gene, environment and mental health, and is very influential, especially during critical periods of life, such as during brain development. Many psychiatric disorders are characterized by an impaired stress response. Interestingly, a robust constellation of findings on the effects of functional polymorphisms of the heat-shock protein 90 FK506 binding protein 5 (FKBP5) gene, in interaction with early life stress, on stress response as well as on psychopathology has emerged during the last decade $[6,7]$. The FKBP5 protein is a co-chaperone regulator of (and regulated by) the glucocorticoid receptor, and thus in turn a modulator of the GRmediated regulatory feed-back on the hypothalamic-pituitary-adrenal (HPA) axis in response to stress $[6,7]$.

Suggestive evidence of functionality has been provided for one polymorphism of the FKBP5 gene, SNP rs1360780. Homozygosity for the minor allele T of the rs1360780 SNP is associated with twice the amount of FKPB5 protein levels in lymphocytes, relative to the other genotypes [8]. The T allele or TT genotype of the SNP rs1360780 (and consequentially the minor allele of the closely linked SNP rs3800373) has been associated with endocrine correlates: higher FKPB5 protein levels
[8]; higher FKPB5 mRNA - plasma cortisol positive correlation [8-12]; reduced basal cortisol levels [8, 9, 12-15]; differential glucocorticoidmediated response [12, 15, 16]; and heightened cortisol response after psychological stress in adults, adolescents and infants (in some cases moderated by childhood adversity) [10, 11, 17, 18]. Clinical associations have also been reported for this allele with better anti-depressant treatment response $[8,10,19,20]$; greater risk of depression [12, 14, 15, 21, 22], suicidal tendencies [8, 23], comorbid anxiety-depression [24], post-traumatic stress disorder [6, 15, 23], and alcohol withdrawal severity [25]; as well as with major depression, aggressive behaviour, suicide attempts, and psychosis in an interaction with adverse life events [15, 26-28]. Moreover, associations with neural correlates of vulnerability to psychopathology have been demonstrated for this allele, such as higher amygdala reactivity [29], and increased threat and negative emotion-related amygdala reactivity in the context of childhood adversity [30]. Negative findings have, however, also been reported [7, 31]. Regarding GWAS studies, two FKBP5 SNPs were among the top ten hits in a GWAS study on daily cortisol secretion, but they did not survive correction for multiple testing [13], whereas no GWAS-significant hits corresponding to SNPs in the FKBP5 gene have been so far related to psychiatric phenotypes. All together, these evidences make the FKBP5 a candidate gene, and the rs1360780 and rs3800373 SNPs candidate markers for studying the effect of constitutional factors of stress response and early adverse life events on adolescent mental health [32].

\section{Aims of the study}

The overall aim of the present study was to promote understanding of how early life stress and FKBP5 polymorphisms related to stress response, interact and contribute to mental health in a populationbased sample of adolescents, and among adolescents exposed to multiple victimisation experience. This study aimed to contribute to answering the following questions: How do environment and stress-related genetic factors interact in relation to propensity to the development of psychiatric symptoms?; Is the interactive effect relevant for several psychiatric symptoms?; Does sex play a role in these interactive influences?

Our hypothesis was that children who grew up in traumatic circumstances and with certain genetic variants have increased vulnerability to the development of psychiatric disorders, compared with those with protective or less environmentally sensitive genetic variants, and who have not experienced traumatic events. Furthermore, we hypothesize that the interaction between genotype and early life stress will be widespread, thus 
indicating a vulnerability model beyond symptom categories.

\section{Materials and methods}

Two independent samples were used: i) adolescents from the 12-year follow-up of a longitudinal study of a large cohort monitored since birth (SESBiC), and ii) adolescents with a mean age of 17 from a large community-based cross-section study (USSS). Ethical approval was received for the SESBiC study (LU 439-93; LU 124-98; M51-07), and for the USSS study (69-07).

\section{South East Sweden Birth Cohort study (SESBiC)}

All mothers of children born between 1 May 1995 and 31 December 1996 in five counties in southern Sweden, with a population of just over $1 \%$ of all Swedes, were asked to participate in the SESBiC study and 1,723 mothers (88\%) agreed to participate [33-37]. The present data come from the 12 year follow-up (mean age 12.0 years, $\mathrm{SD} \pm 0.30$ ). An information letter and a consent form were sent to the parents (i.e. legal guardians). A separate, simplified information letter was enclosed for the child. Two children were deceased, 10 had moved out of the country and 24 had learning problems and were therefore unable to participate. A total of 909 individuals (53.9\%) agreed to participate in the study. The follow-up was carried out at school where research assistants met with the children in small groups and assisted them in answering questionnaires and also in providing a sample of their saliva. The mothers were asked to fill in a package of questionnaires.

\section{Upper Secondary School study (USSS)}

The upper secondary school in Sweden offers three programmes: 1. Higher education preparatory programmes typically humanities, natural science, and social science $(\approx 44 \%$ of all students); 2 . Vocational programmes, typically health and social care, building and construction, hotel and tourism studies ( $\approx 54 \%$ of all students); and 3. Introductory programmes, typically preparatory education, programme-oriented individual options, vocational introduction, individual options, and language introduction, a resource-providing merit for students with different kinds of learning difficulties ( $\approx 2 \%$ of all students) [38]. A total of 51 out of 53 schools participated in the survey and a total of 6,096 students (78\%) were present at the scheduled class-room survey.

The USSS adolescent sample was selected from this community-based sample $(\approx 5 \%)$, of students in the $2^{\text {nd }}$ year upper secondary school system, evenly distributed among structural parameters such as population, commuting patterns and economic structure [4] to represent the national average concerning, sex, birthplace, enrolment from other municipalities and educational programmes. Assuming that students taking the higher education preparatory programmes would have experienced less adverse life events [39], over-sampling of youths with more serious psychosocial problems was achieved by including more students from the vocational and introductory programmes (13\% and $23 \%$ of all students in these programmes, respectively). The mean age was 17.2 years (SD $\pm 0.68)$.

\section{Questionnaires}

The questionnaires were answered by the participants during class hours at school: data on demographics and psychosocial factors; history of the adolescent's exposure to lifetime adverse life events using the Life Incidence of Traumatic Events (LITE) [40] in the SESBiC study, and the Juvenile Victimization Questionnaire (JVQ) [41] in the USSS study. The majority of children has experienced at least one adverse life events during childhood and adolescence [42], and in Sweden $63.0 \%$ of children up to 12 years (no sex difference) had experienced at least one adverse life event during their lifetime, i.e. two or more events could be considered moderate exposure to trauma [43]. Of 17 year olds $84.1 \%$ (83.0\% young men and $85.2 \%$ young women) had experienced at least one victimization event during their lifetime, and $10.3 \%$ had experienced 10 or more events and were categorized as poly-victimized (8.1\% young men and $12.5 \%$ young women) [4]. Since adverse life events were so common, the number of life events at and above the 90th percentile was used in the analyses to catch the most vulnerable group. Symptoms of mental ill-health were assessed by scientifically validated screening tools: the Strengths and Difficulties Questionnaire (SDQ) [44] in the SESBiC study, and the Trauma Symptom Checklist for Children (TSCC) [45] in the USSS study. In the SESBiC study, data on immigrant status and the parent's occupation status were taken from questionnaires filled in by the mother. In the USSS study, participants were asked for information about birth-place, parents' birthplaces, parents' employment, and residence. LITE [43, 46], JVQ [4], SDQ [47], and TSCC [43, 46] are all scientifically validated screening tools with good psychometric properties that have been translated into Swedish and for which Swedish norms have been established.

\section{Genetic analyses}

DNA was extracted according to the manual from saliva samples collected using DNA Self Collection Kit (Oragene ${ }^{\circledR}$ ). Genotyping of the polymorphism 
of interest FKBP5 SNPs rs1360780, and of the highly linked SNP rs3800373, was performed using a fluorescence-based competitive allele-specific PCR (KASPar) assay (KBioscience ${ }^{\circledR}$ ). Allele discrimination was done using SNPviewer2®. The genotype calling was performed blind with regard to psychosocial data. To estimate the quality-rate of genotyping errors, a random repetition of $\sim 13 \%$ of the population-based sample was carried out; the comparison indicated no inconsistencies. Diplotypes were estimated with the EM algorithm using SNP \& Variation Suite 7 (GoldenHelix ${ }^{\circledR}$ ). Genotype frequencies are shown in Table S2. The genotypes were in Hardy-Weinberg equilibrium (Table S2).

SESBiC: Due to internal drop-out, the number of DNA samples from the 909 children that could be analysed, together with the data from the instruments, was $\mathrm{n}=888$ for $F K B P 5$ rs1360780 and $\mathrm{n}=902$ for rs3800373, and $\mathrm{n}=881$ in the haplotype analysis.

USSS: In all 398 adolescents participated. The number of DNA samples that could be analysed together with questionnaire data was $\mathrm{n}=394$ for both FKBP5 rs1360780 and rs3800373 (four DNA samples were missing for each polymorphism) and $\mathrm{n}=390$ in the haplotype analysis. $81 \%$ of the students were in the vocational programme and $19 \%$ in the introductory programme.

\section{Data analysis}

The statistical power has been computed using the Genetic Power Calculator (http://pngu.mgh.harvard.edu/ purcell/gpc/) [48]. Since rs1360780 has been the SNP of interest and it is in high LD with rs3800373, the alpha was kept at 0.05 . In an additive model, the power for a test with heritability equal to $1 \%$ is $85.3 \%$. Thus, the size of the population-based cohort (SESBiC) outdoes the sample size of 781 subjects required for a power of $80 \%$. On the other hand, the USSS cohort is underpowered, although it included more individuals reporting adverse life events, which is a known risk factor for psychopathology. Oversampling for individuals in the high-risk strata has certainly high efficacy in enhancing the power of a study. Group differences were tested using crosstab statistics and Pearson chi-square $\left(\chi^{2}\right)$ for categorical data and t-test (two-sided) for continuous variables. Bivariate correlations were tested, computing the Pearson's correlation coefficient. Genotype group differences in psychiatric symptoms were tested using univariate analysis of variance [49]. Multi-level statistical modelling was used to describe the interaction between environmental and genetic factors. The adjusted multivariate gene-by-environment interaction models were analysed by applying general linear models (i.e. Univariate analysis of variance with Covariates, ANCOVA) using psychiatric symptoms as a scale variable. Genotypes were also grouped as homozygous and heterozygous for the $\mathrm{T}$ (rs1360780) or C (rs3800373) allele in one group and compared with homozygous for the major allele addressing the statistical constraint imposed by the low frequency of the minor alleles. Descriptive statistics were performed and presented for all three genotype groups. The environmental factor - adverse life events - was dichotomized according to [50], into less than 90th percentile vs. 90th percentile and above for the JVQ (10 or more events) and LITE (5 or more events) scales, respectively. As covariates: sex, living with both parents or not, immigrant status, and the parent's occupational status were used to account for known bias factors. Bonferroni correction was applied according to the number of psychobiologically meaningful questions tested and effectively independent SNPs, which is one marker when testing GxE association with the sub-scales (for the SDQ $p \leq 0.01$ and for the TSCC $p \leq$ 0.0083). Effect sizes (Cohen's d) were calculated as the difference of mean score on SDQ/TSCC total scores for the risk genotype between no environmental load and high negative environmental load (90th percentile on LITE/JVQ) divided by the SD for the respective symptom measures. To further validate the findings, partial correlations, adjusted for sex, were performed to test for genotype-dependent environment effects on mental health using continuous measures, and to calculate the difference of correlation coefficients (z) [23]. Linkage disequilibrium ( $\mathrm{r}^{2}$ and $\left.\mathrm{D}^{\prime}\right)$ and haplotypes were estimated with the EM algorithm using SNP \& Variation Suite 7 (GoldenHelix ${ }^{\circledR}$ ).

\section{Results}

Descriptive characteristics

Demographic and genotypic characteristics of the SESBiC (909 (50.1\% boys) 12-year-old adolescents) and USSS (398 (54.3\% boys) 17-yearold adolescents) cohorts are presented in the Supplementary Tables. In the SESBiC cohort the mean age was $12.0 \pm 0.3$ years, and in the USSS cohort $17.2 \pm 0.7$ years. The adolescents in the USSS cohort, as expected, had a higher percentage of parents born outside the country of residence ( $p$ $<0.001$ ), a lower percentage had both parents with a job $(p<0.001)$, and fewer of them lived with their biological parents $(p=0.002)$ compared to the SESBiC cohort (Table S1). Genotype frequencies did not differ significantly between the two cohorts (Table S2). 
The number of adverse life events among the adolescents in the SESBiC cohort (measured as LITE) ranged from 0 to 10 with a mean of $2.7 \pm$ 1.8, while in the USSS cohort (measured as JVQ) ranged from 0 to 32 with a mean of $4.6 \pm 5.0$. The mean score of total psychiatric symptoms in the SESBiC cohort was 10.6 (SD \pm 5.76 ) (measured as SDQ total) and in the USSS cohort 31.6 (SD \pm 23.50) (measured as TSCC total) (Table S3 and S3b).

Adverse life events were as common in girls as in boys in the SESBiC cohort, whereas in the USSS cohort females reported more events ( $p=0.040)$. Regarding mental health symptoms, in both cohorts sex differences were found in the SDQ and TSCC total scores as well as in the sub-scales, though more marked in the USSS cohort (table S3a and S3b). Symptoms of conduct and hyperactivity/inattention problems were more common among males, while symptoms of emotional problems and more positive prosocial behaviour were more often reported by females in the SESBiC cohort (Table 3a). Symptoms of sexual concerns were more common among males, while symptoms of anger, anxiety, depression, dissociation and posttraumatic stress were more often reported by females in the USSS cohort (Table 3b). The correlation between the SDQ total score in the SESBiC cohort and the different SDQ subscales was low to high $(\mathrm{r}=0.363-0.912 ; p<$ 0.001), while between the TSCC total score in the USSS cohort and all the different TSCC subscales correlation was high $(\mathrm{r}=0.687-0.900 ; p<0.001)$ (Table S4).

\section{Main effects}

Both sexes reported higher scores on SDQ and TSCC total score and subscales if they had experienced adverse life events at or above the 90th percentile $(p=0.044$ to $p<0.001$ and $p=0.023$ to $p<0.001$; respectively). The main genotype effects on SDQ and TSCC scores were not present, except in the USSS cohort, where carriers of the minor allele of the FKBP5 rs3800373 SNP reported significantly more psychiatric symptoms ( $p=$ 0.037; F = 3.331) (Table S5).

\section{Gene-by-Environment interaction effects ( $G \times E)$}

In the SESBiC cohort, a GxE interaction effect of FKBP5 rs3800373 was observed on the SDQ total score $\left(p=0.019 ; R^{2}=0.030\right)$. Among adolescents with adverse life events at or above the $90^{\text {th }}$ percentile, C carriers displayed the highest SDQ score, compared to the AA genotype, after adjustment for potential confounders. No sex differences were present, and genotype main effects were absent, as well as the effects of rs1360780 genotype (Table 1). At the sub-scales level, there was only a nominally significant GxE effect on hyperactivity/inattention (Table S6a).

In the USSS cohort, both a gene main effect as well as a GxE interaction effect was found in the total TSCC score. The rs3800373 C carrier and rs1360780 T carrier genotypes were associated with higher scores among adolescents who had experienced adverse life events at or above the $90^{\text {th }}$ percentile compared to individuals who were homozygous for the AA and CC genotypes, respectively, adjusted for potential confounders ( $p$ $=0.001 ; R^{2}=0.260$ and $p=0.007 ; R^{2}=0.254$; respectively) (Table 1 ). Nominally significant results in accordance with the same pattern of association were found for the sub-scales for Anger, Anxiety, Depression, Dissociation and Posttraumatic stress, but not for Sexual concerns (Table S6b). After Bonferroni correction, only the rs3800373xE effect on Anxiety, Depression, Anger, and Dissociation, and the rs1360780xE on Dissociation remained significant. When splitting the sample by sex because of its statistical significance in the model $(p<0.001)$, the GxE effects were only found in males (data not shown).

The effect sizes were highest for the rs3800373 and rs1360780 SNPs in the USSS cohort $(d=0.76$ and $d=0.56$, respectively), and moderate for the rs3800373 SNP in the SESBiC cohort $(d=0.47)$, with individuals carrying the minor allele of these SNPs having greater psychiatric symptoms than homozygous individuals for the most common alleles. In both cohorts, GxE effects were present in a genotype dose-dependent manner, with heterozygous individuals displaying intermediate scores in the presence of adverse life events, compared to both homozygous genotypes (Figure 1).

Gene-dependent environment-psychiatric symptoms correlation effects

Partial correlations, adjusted for sex, substantially corroborated these findings in the USSS cohort but not in the SESBiC cohort. High correlations were present between the adverse life events and psychiatric symptoms among homozygous carriers of the minor allele of the rs3800373 and rs1360780 SNPs in the USSS cohort $(r=0.888$; AA/CC: $Z=$ 4.45; and $r=0.841$; CC/TT: $Z=4.19$, respectively) (Table S7). Thus, this confirms that the interaction effect between genotype and adverse life events in psychiatric symptoms is characterized by a genotype, as well as a stress-dosage load on number of psychiatric symptoms in adolescents.

\section{Haplotype analyses}

As the two markers are in high Linkage Disequilibrium $\left(\mathrm{D}^{\prime}=0.98\right.$ and $\mathrm{R}^{2}=0.86$ in the SESBiC cohort, and $\mathrm{D}^{\prime}=0.98$ and $\mathrm{R}^{2}=0.82$ in the 
IUSS cohort), the analyses were re-performed using diplotypes, which are inferred combinations of haplotypes (Table S8). As expected, a significant GxE was only present in the USSS cohort, with carriers of the diplotype containing the minor alleles of the rs3800373 and rs1360780 SNPs reporting more psychiatric symptoms if exposed to adverse life events ( $p=0.021 ; R^{2}=0.255$ ) (Table S9). Lastly, GxE effects were more evident in males (data not shown).

\section{Discussion}

The present study investigated the interactive effect of genetic factors of stress responsiveness and early life adversity on psychiatric symptoms in two independent samples, one population-based sample of young individuals (SESBiC cohort) and one sample of older adolescents enriched for polyvictimised adolescents (USSS cohort). The findings indicate that the least common functional variations of the FKBP5 gene, a regulator of glucocorticoid receptor function, in an interaction with adverse life events, are associated with symptoms of mental illhealth among both 12 and 17 year-old adolescents. This is in line with previous findings in adults of a FKBP5 genotype-by-childhood maltreatment interaction effect on clinical phenotypes, such as depression, PTSD, psychosis, suicide attempts, and on aggressive behaviour [18, 22, 23, 26, 28, 51, 52], suicidal tendencies, as well as on threat-related right dorsal amygdala reactivity in adolescents reactivity [30].

Key-features of psychiatric disorders, as defined by the DSM, are their phenotypical and biological heterogeneity, complexity, overlap, and interdependence. Our hypothesis was confirmed: adolescents who grew up in adverse circumstances, and with certain genetic variants, report a higher level of psychological symptoms, and that this interaction between genotype and early life stress illustrates a vulnerability model beyond symptom categories. On the other hand, those with protective or less environmental sensitive genetic variants and who have not experienced traumatic events display decreased propensity for the development of psychiatric disorders.

Too little attention has been devoted to children and adolescents as victims, in view of the social and personal burden of the consequences, and the costbenefit advantage of early interventions. The emphasis in the present study has been on individuals at a particularly crucial time of life and of brain development (i.e. adolescence), and in fragile conditions (i.e. poly-victimisation). Furthermore, sex differences which are common in psychiatric disease vulnerability, presentation, and outcomes, were also investigated.

To our knowledge, no FKBP5 gene by adverse life events study on a broad spectrum of psychopathology symptoms has been performed for young adolescents and poly-victimized adolescents. Hence the present study presents novel findings valuable in the context of future meta-analyses. The similar results found in two independent and relatively large cohorts, despite the use of different self-reporting instruments, corroborate each other, providing support for their robustness. They are in line with the previous results of clinical, psychophysiological and neuroimaging studies for $F K B P 5$, indicating the $\mathrm{T}$ allele as a risk factor for psychopathology $[6,8,10,12,14,15,19-27,29$, 30]. In fact, the TT genotype of rs1360780, which leads to higher FKBP5 protein levels [7, 8], has been associated with an altered physiological stress response and heightened risk of stress [6-18]. Binder and colleagues suggested a putative enhancing function on gene transcription for the $\mathrm{T}$ allele by the formation of a TATA box, as well as differential chromatin conformations and interactions of long-range enhancers with the transcription start site, which would influence the response to the glucocorticoid receptor activation triggered by early life adversity [6].

Results were more prominent in males in the USSS cohort. Sex differences in neuroscience exist in relation to brain anatomy, function, chemistry and also the prevalence and nature of psychiatric disorders [53-55]. Substantial evidence indicates that psychosocial factors interact with sex/sex hormones, and with the genetic make-up, to influence individual stress response to environmental stressors, which is an important factor linked to psychiatric disorders. Indeed, several genetic association studies on psychiatric symptoms reported sex effects mediating gene-byenvironmental interactions on adolescent mental health, thus stressing the importance of considering sex differences in biological psychiatry. In the present study, the GxE effects were more evident in males, although the direction of association was similar in females. Interestingly, the rs3800373 genotype displayed an effect in male but not female young adults on cortisol response to psychosocial stress [56]. The FKBP5 is a co-chaperone of the progesterone and androgen receptor complex [7], thus making sex dimorphic influences plausible.

Gene by environment interactions in psychiatry still debated today, and the biological underpinnings of these interactions remain largely unknown [2, 57, 58]. It has been suggested that the FKBP5 gene variants examined in the present study have genetic and endocrine functional effects, and ultimately 
predispose psychiatric disorders [7].. Differential cortisol recovery response after psychosocial stress has been demonstrated in young adults [10, 59], and also cortisol reactivity to stressful situations in infants, depending on the FKBP5 genotype [11]. Binder and colleagues have recently provided evidence of a childhood trauma-dependent epigenetic mechanism [6], by demonstrating an allele-specific, childhood trauma, dependent DNA methylation of FKBP5 for proneness to stressrelated psychiatric disorders [6]. Thus, this makes it one putative mechanism behind the FKBP5 gene by adverse life events effect on mental ill-health observed in the present study.

The SESBiC cohort is a representative sample of young Swedish adolescents [36], while the USSS cohort comprises a group of adolescents with a greater risk of having experienced more adverse life events $[60,61]$, as reflected by the fact that the $\geq$ $90^{\text {th }}$ percentile of ALE in the SESBiC cohort included 5 or more events, while in the USSS cohort it comprised 10 or more. The interaction between FKBP5 SNP rs1360780 and rs3800373 with adverse life events was associated with mental health problems, after controlling for sex and ethnosocio-economic factors. This was particularly prominent among poly-victimized older male adolescents in the USSS cohort, probably due to a cumulative effect of age and multiple exposure to adverse life events which, combined with genetic vulnerability, results in more psychiatric symptoms. Time, type, and dosage of environmental exposure to adverse life events are certainly of importance for the development of posttraumatic symptomatology [3]. Retrospectively assessed early life adversity, in interaction with FKBP5 genotype, but not adult trauma, has for instance been shown to predict psychopathology [62], thus stressing the importance of early investigations.

The strengths of the present study are: i) the inclusion of two relatively large independent samples; ii) the investigation of adolescent individuals, which permits identification of early predictors and reduces the retrospective time interval for early life adversity recall; iii) the use of well-validated screening instruments; iv) the study of a broad range of mental health symptoms; and v) the comparability of results obtained with different study set-ups, phenotypic outcome variables, and the nature of the environmental factor. The limitations include a relatively high drop-out of individuals who are often at the extreme end of the phenotypic spectrum; the cross-sectional retrospective study design; and the loss of statistical significance of the results related to the sub-scales if correction for multiple-testing is applied, although the genetic and statistical analyses have been unidirectionally hypothesis-driven.
In contrast with the proportion of phenotypic variance estimated by heritability studies, single common genetic variants have been shown to account for only a very small proportion of variance for complex behavioural and psychiatric phenotypes [63], presumably because environmental factors are not taken into account of. False positive findings, together with the low statistical power of many studies, have hindered our understanding of the pathological underpinning of psychiatric disorders and have restricted advances in clinical practice [2, 64]. As highlighted by Munafo et al. and Duncan and Keller [2, 65], wellpowered direct replications are needed to arrive at a robust, reliable and reproducible GxE finding, and also converging evidence from preclinical and neuroimaging studies should corroborate a GxE finding. Accordingly, the present study attempted to test a previous hypothesis and replication of potential findings in an independent sample, by using a similar set-up with regard to phenotypic variable, genetic polymorphisms, statistical model, environmental moderator, and inclusion of both sexes. The two studies were planned independently, and therefore the assessment tools differ. While, on the one hand, the employment of the same tools in both studies would have been highly desirable, it is a strength of the present results that similar findings are obtained, independently of which measure is used. This mirrors what often happens in the literature, where multi-site studies employing the same protocol are rare and the resources demanding. It is true that methodological differences are often claimed as the explanatory factor for discrepancies in the results of many genetic association studies. However robust results should not be biased by such minor variances. It is important to note that, subsequently to correction for multiple-testing, most of the results related to the sub-scales can only be deemed nominally significant, thus calling for independent replications. On the other hand, since the dimensions of the sub-scales are interrelated, the total SDQ and TSCC scores serve the purpose of the present study better, i.e. to investigate genetic correlates of a psychiatric dimensional measure across its full range. The statistically significant findings in the USSS cohort were associated with moderate effect sizes. Only a very small proportion of phenotypic variance can be explained by single common genetic variants [63], and gene by gene interaction should also be considered [2], thus genetic score indexes and GWAS approaches are highly desirable.

To conclude, these findings heighten the generalisability of previous results in adult clinical samples, and of neuroimaging findings, to adolescents' behaviour and psychiatric symptoms. 
Moreover, in line with more and more frequent evidence of overlapping genetic constructs across psychiatric disorders [49, 66], the present $\mathrm{GxE}$ findings suggest a shared $\mathrm{GxE}$ effect across different mental health problems, moving beyond strictly immobile psychiatric definitions and categories, towards a nosology informed by neurobiology of the disease [2], although no causality relationship could be addressed.

\section{Role of funding source}

Grants from the following research funds are acknowledged: The Swedish Crime Victim Compensation and Support Authority (09042/2008), the Swedish Council for Working Life and Social Research (2006-2014) to CG.S.; and the Swedish Council for Working Life and Social Research (2011-0627) and Uppsala University to E.C. The funding sources had no further role in study design, the collection, analysis and interpretation of data, the writing of the report, or the decision to submit the paper for publication.

\section{Conflict of interest}

None declared by any of the authors.

\section{Acknowledgements}

The authors would like to sincerely thank all the children and adolescents who participated in this study,; and also Professor Lars Oreland and Doctor Niklas Nordquist for their contribution to the genetic analyses of the SESBiC study.

\section{References}

1. Spear LP (2000) The adolescent brain and age-related behavioral manifestations. Neurosci Biobehav Rev 24:417-463

2. Munafo MR, Zammit S, Flint J (2014) Practitioner Review: A critical perspective on gene-environment interaction models what impact should they have on clinical perceptions and practice? J Child Psychol Psychiatry

3. Heim C, Binder EB (2012) Current research trends in early life stress and depression: review of human studies on sensitive periods, gene-environment interactions, and epigenetics. Exp Neurol 233:102-111

4. Aho N, Gren-Landell M, Svedin CG (2014) The Prevalence of Potentially Victimizing Events, Poly-Victimization, and Its Association to Sociodemographic Factors: A Swedish Youth Survey. J Interpers Violence
5. Manuck SB, McCaffery JM (2014) Geneenvironment interaction. Annu Rev Psychol 65:41-70

6. Klengel T, Mehta D, Anacker C, RexHaffner M, Pruessner JC, Pariante CM, Pace TW, Mercer KB, Mayberg HS, Bradley B, Nemeroff CB, Holsboer F, Heim CM, Ressler KJ, Rein T, Binder EB (2013) Allele-specific FKBP5 DNA demethylation mediates gene-childhood trauma interactions. Nat Neurosci 16:3341

7. Zannas AS, Binder EB (2014) Geneenvironment interactions at the FKBP5 locus: sensitive periods, mechanisms and pleiotropism. Genes Brain Behav 13:25-37

8. Binder EB, Salyakina D, Lichtner P, Wochnik GM, Ising M, Putz B, Papiol S, Seaman S, Lucae S, Kohli MA, Nickel T, Kunzel HE, Fuchs B, Majer M, Pfennig A, Kern N, Brunner J, Modell S, Baghai T, Deiml T, Zill P, Bondy B, Rupprecht R, Messer T, Kohnlein O, Dabitz H, Bruckl T, Muller N, Pfister H, Lieb R, Mueller JC, Lohmussaar E, Strom TM, Bettecken $\mathrm{T}$, Meitinger T, Uhr M, Rein T, Holsboer F, Muller-Myhsok B (2004)

Polymorphisms in FKBP5 are associated with increased recurrence of depressive episodes and rapid response to antidepressant treatment. Nat Genet 36:1319-1325

9. Menke A, Klengel T, Rubel J, Bruckl T, Pfister H, Lucae S, Uhr M, Holsboer F, Binder EB (2013) Genetic variation in FKBP5 associated with the extent of stress hormone dysregulation in major depression. Genes Brain Behav 12:289296

10. Ising M, Depping AM, Siebertz A, Lucae S, Unschuld PG, Kloiber S, Horstmann S, Uhr M, Muller-Myhsok B, Holsboer F (2008) Polymorphisms in the FKBP5 gene region modulate recovery from psychosocial stress in healthy controls. Eur J Neurosci 28:389-398

11. Luijk MP, Velders FP, Tharner A, van Ijzendoorn $\mathrm{MH}$, Bakermans-Kranenburg MJ, Jaddoe VW, Hofman A, Verhulst FC, Tiemeier H (2010) FKBP5 and resistant attachment predict cortisol reactivity in infants: gene-environment interaction. Psychoneuroendocrinology 35:1454-1461

12. Fujii T, Hori H, Ota M, Hattori K, Teraishi T, Sasayama D, Yamamoto N, Higuchi T, Kunugi H (2014) Effect of the common functional FKBP5 variant (rs1360780) on the hypothalamic-pituitary-adrenal axis and peripheral blood gene expression. Psychoneuroendocrinology 42:89-97 
13. Velders FP, Kuningas M, Kumari M, Dekker MJ, Uitterlinden AG, Kirschbaum C, Hek K, Hofman A, Verhulst FC, Kivimaki M, Van Duijn CM, Walker BR, Tiemeier H (2011) Genetics of cortisol secretion and depressive symptoms: a candidate gene and genome wide association approach.

Psychoneuroendocrinology 36:1053-1061

14. Zobel A, Schuhmacher A, Jessen F, Hofels $\mathrm{S}$, von Widdern $\mathrm{O}$, Metten M, Pfeiffer U, Hanses C, Becker T, Rietschel M, Scheef L, Block W, Schild HH, Maier W, Schwab SG (2010) DNA sequence variants of the FKBP5 gene are associated with unipolar depression. Int J Neuropsychopharmacol 13:649-660

15. Collip D, Myin-Germeys I, Wichers M, Jacobs N, Derom C, Thiery E, Lataster T, Simons C, Delespaul P, Marcelis M, van Os J, van Winkel R (2013) FKBP5 as a possible moderator of the psychosisinducing effects of childhood trauma. $\mathrm{Br} \mathrm{J}$ Psychiatry 202:261-268

16. Brent D, Melhem N, Ferrell R, Emslie G, Wagner KD, Ryan N, Vitiello B, Birmaher B, Mayes T, Zelazny J, Onorato M, Devlin B, Clarke G, DeBar L, Keller M (2010) Association of FKBP5 polymorphisms with suicidal events in the Treatment of Resistant Depression in Adolescents (TORDIA) study. Am J Psychiatry 167:190-197

17. Pagliaccio D, Luby JL, Bogdan R, Agrawal A, Gaffrey MS, Belden AC, Botteron KN, Harms MP, Barch DM (2014) Stress-system genes and life stress predict cortisol levels and amygdala and hippocampal volumes in children. Neuropsychopharmacology 39:1245-1253

18. Ajnakina O, Borges S, Di Forti M, Patel Y, Xu X, Green P, Stilo SA, Kolliakou A, Sood P, Marques TR, David AS, Prata D, Dazzan P, Powell J, Pariante C, Mondelli V, Morgan C, Murray RM, Fisher HL, Iyegbe C (2014) Role of Environmental Confounding in the Association between FKBP5 and First-Episode Psychosis. Front Psychiatry 5:84

19. Lekman M, Laje G, Charney D, Rush AJ, Wilson AF, Sorant AJ, Lipsky R, Wisniewski SR, Manji H, McMahon FJ, Paddock S (2008) The FKBP5-gene in depression and treatment response--an association study in the Sequenced Treatment Alternatives to Relieve Depression (STAR*D) Cohort. Biol Psychiatry 63:1103-1110

20. Kirchheiner J, Lorch R, Lebedeva E, Seeringer A, Roots I, Sasse J, Brockmoller
$\mathrm{J}$ (2008) Genetic variants in FKBP5 affecting response to antidepressant drug treatment. Pharmacogenomics 9:841-846

21. Lavebratt C, Aberg E, Sjoholm LK, Forsell Y (2010) Variations in FKBP5 and BDNF genes are suggestively associated with depression in a Swedish populationbased cohort. J Affect Disord 125:249-255

22. Appel K, Schwahn C, Mahler J, Schulz A, Spitzer C, Fenske K, Stender J, Barnow S, John U, Teumer A, Biffar R, Nauck M, Volzke H, Freyberger HJ, Grabe HJ (2011) Moderation of adult depression by a polymorphism in the FKBP5 gene and childhood physical abuse in the general population. Neuropsychopharmacology 36:1982-1991

23. Binder EB, Bradley RG, Liu W, Epstein MP, Deveau TC, Mercer KB, Tang Y, Gillespie CF, Heim CM, Nemeroff CB, Schwartz AC, Cubells JF, Ressler KJ (2008) Association of FKBP5 polymorphisms and childhood abuse with risk of posttraumatic stress disorder symptoms in adults. Jama 299:1291-1305

24. Minelli A, Maffioletti E, Cloninger CR, Magri C, Sartori R, Bortolomasi M, Congiu C, Bignotti S, Segala M, Giacopuzzi M, Gennarelli M (2013) Role of allelic variants of FK506-binding protein 51 (FKBP5) gene in the development of anxiety disorders. Depress Anxiety 30:1170-1176

25. Huang MC, Schwandt ML, Chester JA, Kirchhoff AM, Kao CF, Liang T, Tapocik JD, Ramchandani VA, George DT, Hodgkinson CA, Goldman D, Heilig M (2014) FKBP5 moderates alcohol withdrawal severity: human genetic association and functional validation in knockout mice.

Neuropsychopharmacology 39:2029-2038

26. Bevilacqua L, Carli V, Sarchiapone M, George DK, Goldman D, Roy A, Enoch MA (2012) Interaction Between FKBP5 and Childhood Trauma and Risk of Aggressive Behavior. Archives of General Psychiatry 69:62-70

27. Szczepankiewicz A, LeszczynskaRodziewicz A, Pawlak J, Narozna B, Rajewska-Rager A, Wilkosc M, Zaremba D, Maciukiewicz M, Twarowska-Hauser J (2014) FKBP5 polymorphism is associated with major depression but not with bipolar disorder. J Affect Disord 164:33-37

28. Roy A, Gorodetsky E, Yuan Q, Goldman D, Enoch MA (2010) Interaction of FKBP5, a stress-related gene, with childhood trauma increases the risk for 
attempting suicide.

Neuropsychopharmacology 35:1674-1683

29. Fani N, Gutman D, Tone EB, Almli L, Mercer KB, Davis J, Glover E, Jovanovic T, Bradley B, Dinov ID, Zamanyan A, Toga AW, Binder EB, Ressler KJ (2013) FKBP5 and attention bias for threat: associations with hippocampal function and shape. JAMA Psychiatry 70:392-400

30. White MG, Bogdan R, Fisher PM, Munoz KE, Williamson DE, Hariri AR (2012) FKBP5 and emotional neglect interact to predict individual differences in amygdala reactivity. Genes Brain Behav 11:869-878

31. Dunn EC, Solovieff N, Lowe SR, Gallagher PJ, Chaponis J, Rosand J, Koenen KC, Waters MC, Rhodes JE, Smoller JW (2014) Interaction between genetic variants and exposure to Hurricane Katrina on post-traumatic stress and posttraumatic growth: a prospective analysis of low income adults. J Affect Disord 152154:243-249

32. Binder EB (2009) The role of FKBP5, a co-chaperone of the glucocorticoid receptor in the pathogenesis and therapy of affective and anxiety disorders. Psychoneuroendocrinology 34 Suppl 1:S186-195

33. Agnafors S, Comasco E, Bladh M, Sydsjo G, Dekeyser L, Oreland L, Svedin CG (2013) Effect of gene, environment and maternal depressive symptoms on preadolescence behavior problems - a longitudinal study. Child Adolesc Psychiatry Ment Health 7:10

34. Agnafors S, Sydsjo G, Dekeyser L, Svedin CG (2013) Symptoms of depression postpartum and 12 years later-associations to child mental health at 12 years of age. Matern Child Health J 17:405-414

35. Hook B, Cederblad M, Berg R (2006) Prenatal and postnatal maternal smoking as risk factors for preschool children's mental health. Acta Paediatr 95:671-677

36. deKeyser L, Svedin CG, Agnafors S, Bladh M, Sydsjo G (2014) Multiinformant reports of mental health in Swedish-born children of immigrants and children born to non-immigrants - the SESBiC-study. BMC Pediatr 14:95

37. Dekeyser L, Svedin CG, Agnafors S, Sydsjo G (2011) Self-reported mental health in 12-year-old second-generation immigrant children in Sweden. Nord J Psychiatry 65:389-395

38. Skolverket (2011) http://www.skolverket.se/omskolverket/andra-sprak-och-lattlast/in- english/the-swedish-education-system. In, Stockholm

39. Breslau N, Kessler RC, Chilcoat HD, Schultz LR, Davis GC, Andreski P (1998) Trauma and posttraumatic stress disorder in the community: the 1996 Detroit Area Survey of Trauma. Arch Gen Psychiatry 55:626-632

40. Greenwald R, Rubin A (1999) Assessment of posttraumatic symptoms in children: Development and preliminary validation of parent and child scales. Research on Social Work Practice 9:61-75

41. Finkelhor D, Hamby SL, Ormrod R, Turner H (2005) The Juvenile Victimization Questionnaire: reliability, validity, and national norms. Child Abuse Negl 29:383-412

42. Finkelhor D, Turner H, Ormrod R, Hamby SL (2009) Violence, abuse, and crime exposure in a national sample of children and youth. Pediatrics 124:1411-1423

43. Gustafsson PE, Nilsson D, Svedin CG (2009) Polytraumatization and psychological symptoms in children and adolescents. Eur Child Adolesc Psychiatry 18:274-283

44. Lundh LG, Wangby-Lundh M, Bjarehed J (2008) Self-reported emotional and behavioral problems in Swedish 14 to 15year-old adolescents: a study with the selfreport version of the Strengths and Difficulties Questionnaire. Scand J Psychol 49:523-532

45. Briere J, Johnson K, Bissada A, Damon L, Crouch J, Gil E, Hanson R, Ernst V (2001) The Trauma Symptom Checklist for Young Children (TSCYC): reliability and association with abuse exposure in a multisite study. Child Abuse Negl 25:10011014

46. Nilsson D, Gustafsson PE, Svedin CG (2010) Self-reported potentially traumatic life events and symptoms of post-traumatic stress and dissociation. Nord J Psychiatry 64:19-26

47. Smedje H, Broman JE, Hetta J, von Knorring AL (1999) Psychometric properties of a Swedish version of the "Strengths and Difficulties Questionnaire". Eur Child Adolesc Psychiatry 8:63-70

48. Purcell S, Cherny SS, Sham PC (2003) Genetic Power Calculator: design of linkage and association genetic mapping studies of complex traits. Bioinformatics 19:149-150

49. Lee SH, Ripke S, Neale BM, Faraone SV, Purcell SM, Perlis RH, Mowry BJ, Thapar A, Goddard ME, Witte JS, Absher D, Agartz I, Akil H, Amin F, Andreassen OA, 
Anjorin A, Anney R, Anttila V, Arking DE, Asherson P, Azevedo MH, Backlund L, Badner JA, Bailey AJ, Banaschewski T, Barchas JD, Barnes MR, Barrett TB, Bass $\mathrm{N}$, Battaglia A, Bauer M, Bayes M, Bellivier F, Bergen SE, Berrettini W, Betancur C, Bettecken T, Biederman J, Binder EB, Black DW, Blackwood DHR, Bloss CS, Boehnke M, Boomsma DI, Breen G, Breuer R, Bruggeman R, Cormican P, Buccola NG, Buitelaar JK, Bunney WE, Buxbaum JD, Byerley WF, Byrne EM, Caesar S, Cahn W, Cantor RM, Casas M, Chakravarti A, Chambert K, Choudhury K, Cichon S, Cloninger CR, Collier DA, Cook EH, Coon H, Cormand B, Corvin A, Coryell WH, Craig DW, Craig IW, Crosbie J, Cuccaro ML, Curtis D, Czamara D, Datta S, Dawson G, Day R, De Geus EJ, Degenhardt F, Djurovic S, Donohoe GJ, Doyle AE, Duan JB, Dudbridge F, Duketis E, Ebstein RP, Edenberg HJ, Elia J, Ennis S, Etain B, Fanous A, Farmer AE, Ferrier IN, Flickinger M, Fombonne E, Foroud T, Frank J, Franke B, Fraser C, et al. (2013) Genetic relationship between five psychiatric disorders estimated from genome-wide SNPs. Nat Genet 45:984-+

50. Finkelhor D, Ormrod RK, Turner HA, Hamby SL (2005) Measuring polyvictimization using the juvenile victimization questionnaire. Child Abuse \& Neglect 29:1297-1312

51. Xie P, Kranzler HR, Poling J, Stein MB, Anton RF, Farrer LA, Gelernter J (2010) Interaction of FKBP5 with childhood adversity on risk for post-traumatic stress disorder. Neuropsychopharmacology 35:1684-1692

52. Zimmermann P, Bruckl T, Nocon A, Pfister H, Binder EB, Uhr M, Lieb R, Moffitt TE, Caspi A, Holsboer F, Ising M (2011) Interaction of FKBP5 gene variants and adverse life events in predicting depression onset: results from a 10-year prospective community study. Am J Psychiatry 168:1107-1116

53. Cahill L (2006) Why sex matters for neuroscience. Nat Rev Neurosci 7:477-484

54. Cosgrove KP, Mazure CM, Staley JK (2007) Evolving knowledge of sex differences in brain structure, function, and chemistry. Biol Psychiatry 62:847-855

55. Toffoletto S, Lanzenberger R, Gingnell M, Sundstrom-Poromaa I, Comasco E (2014) Emotional and cognitive functional imaging of estrogen and progesterone effects in the female human brain: a systematic review.

Psychoneuroendocrinology 50:28-52

56. Mahon PB, Zandi PP, Potash JB, Nestadt G, Wand GS (2013) Genetic association of FKBP5 and CRHR1 with cortisol response to acute psychosocial stress in healthy adults. Psychopharmacology (Berl) 227:231-241

57. $\quad$ Feder A, Nestler EJ, Charney DS (2009) Psychobiology and molecular genetics of resilience. Nat Rev Neurosci 10:446-457

58. Caspi A, Moffitt TE (2006) Geneenvironment interactions in psychiatry: joining forces with neuroscience. Nat Rev Neurosci 7:583-590

59. Buchmann AF, Holz N, Boecker R, Blomeyer D, Rietschel M, Witt SH, Schmidt MH, Esser G, Banaschewski T, Brandeis D, Zimmermann US, Laucht M (2014) Moderating role of FKBP5 genotype in the impact of childhood adversity on cortisol stress response during adulthood. Eur Neuropsychopharmacol 24:837-845

60. Gren-Landell M, Aho N, Carlsson E, Jones A, Svedin CG (2013) Posttraumatic stress symptoms and mental health services utilization in adolescents with social anxiety disorder and experiences of victimization. Eur Child Adolesc Psychiatry 22:177-184

61. Gren-Landell M, Aho N, Andersson G, Svedin CG (2011) Social anxiety disorder and victimization in a community sample of adolescents. J Adolesc 34:569-577

62. Binder EB, Nemeroff CB (2010) The CRF system, stress, depression and anxietyinsights from human genetic studies. Mol Psychiatry 15:574-588

63. Gratten J, Wray NR, Keller MC, Visscher PM (2014) Large-scale genomics unveils the genetic architecture of psychiatric disorders. Nat Neurosci 17:782-790

64. Heininga VE, Oldehinkel AJ, Veenstra R, Nederhof E (2015) I just ran a thousand analyses: benefits of multiple testing in understanding equivocal evidence on gene-environment interactions. PLoS One 10:e0125383

65. Duncan LE, Keller MC (2011) A critical review of the first 10 years of candidate gene-by-environment interaction research in psychiatry. Am J Psychiatry 168:10411049

66. Smoller JW, Craddock N, Kendler K, Lee $\mathrm{PH}$, Neale BM, Nurnberger JI, Ripke S, Santangelo S, Sullivan PF, Consortium PG (2013) Identification of risk loci with shared effects on five major psychiatric 
disorders: a genome-wide analysis. Lancet 381:1371-1379 
Figure 1

Relation of adverse life events ( $<90$ th percentile vs. $\geq 90$ th percentile) to estimated marginal means of psychiatric symptoms in adolescents (SDQ in the SESBiC cohort and TSCC in the USSS cohort) by FKBP5 genotype

\section{SESBiC cohort}

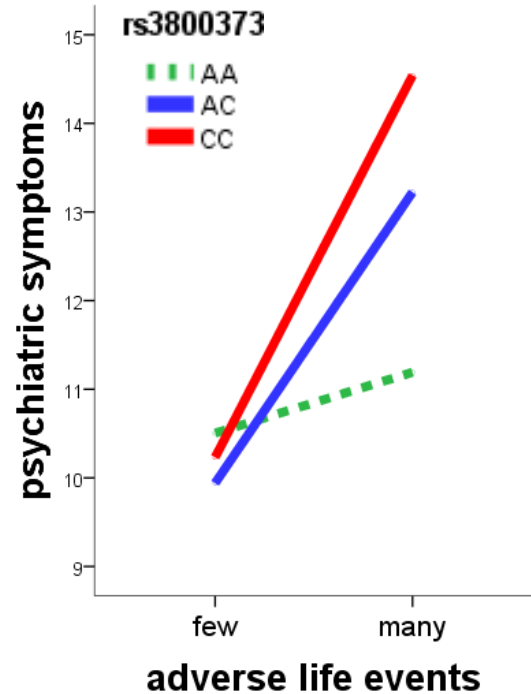

$\mathrm{GxE}: p=0.054\left(\mathbf{0 . 0 1 9 ^ { \# }}\right)$

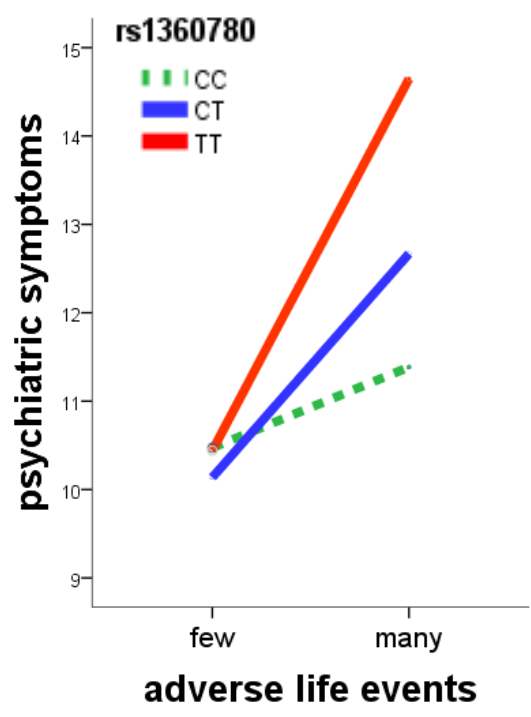

GXE: $p=0.232\left(0.127^{\#}\right)$

\section{USSS cohort}

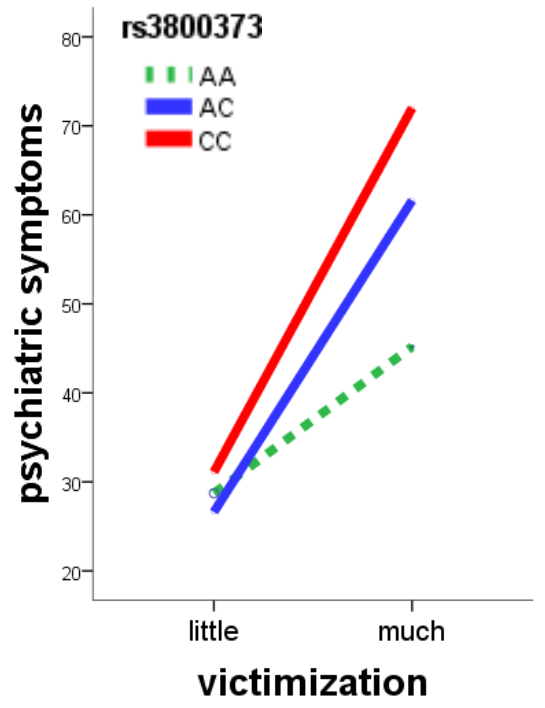

$\mathrm{GxE}: p=0.004\left(0.001^{\#}\right)$

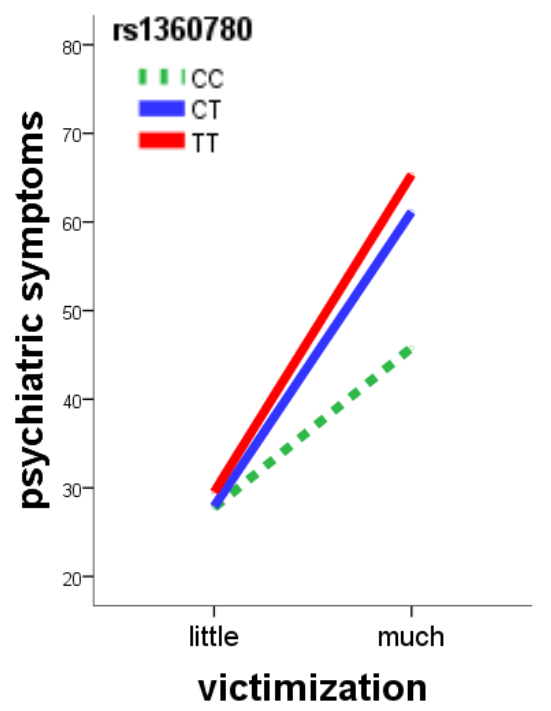

$\mathrm{GxE}: p=0.032\left(0.007^{\#}\right)$ 
Table 1

Interaction effect of FKBP5 genotype and adverse life events associated with psychiatric symptoms (assessed with SDQ and TSCC) in adolescents of the SESBiC and USSS cohorts, respectively

\begin{tabular}{|c|c|c|c|c|c|c|c|}
\hline Cohort & $\begin{array}{c}\text { FKBP5 } \\
\text { genotypes }\end{array}$ & Participants & $\begin{array}{l}\text { ALE }<90 \text { th } \\
\text { percentile }\end{array}$ & Participants & $\begin{array}{l}\text { ALE } \geq 90 \text { th } \\
\text { percentile }\end{array}$ & GLM $^{\$}$ & $\mathbf{R}^{2}$ \\
\hline & & $\mathrm{N}$ & $\begin{array}{l}\text { mean SDQ } \\
\text { score (SD) }\end{array}$ & $\mathbf{N}$ & $\begin{array}{l}\text { mean SDQ } \\
\text { score (SD) }\end{array}$ & $p$ & \\
\hline \multirow[t]{9}{*}{ SESBiC } & rs3800373 & & & & & $\begin{array}{c}E=\mathbf{0 . 0 1 0} ; \mathrm{G}=0.307 \\
\mathrm{G} x \mathrm{E}=\mathbf{0 . 0 4 8}\end{array}$ & 0.018 \\
\hline & AA & 449 & $10.5(6.01)$ & 68 & $11.4(5.65)$ & $\mathrm{E}<0.001^{\#} ; \mathrm{G}=0.156^{\#} ;$ & $0.030^{\#}$ \\
\hline & $A C$ & 272 & $9.9(5.37)$ & 57 & $13.4(5.06)$ & $\mathrm{GxE}=\mathbf{0 . 0 1 9 ^ { \# }}$ & \\
\hline & $\mathrm{CC}$ & 52 & $10.2(5.56)$ & 4 & $14.8(6.02)$ & & \\
\hline & rs1360780 & & & & & $\begin{array}{c}E=0.010 ; G=0.424 \\
G x E=0.237\end{array}$ & 0.014 \\
\hline & $\mathrm{CC}$ & 422 & $10.5(5.93)$ & 61 & $11.6(5.70)$ & 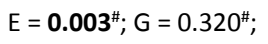 & $0.025^{\#}$ \\
\hline & $\mathrm{CT}$ & 281 & $10.1(5.62)$ & 61 & $12.9(5.29)$ & $\mathrm{GxE}=0.127^{\#}$ & \\
\hline & $\mathrm{TT}$ & 58 & $10.3(5.62)$ & 5 & $14.8(5.22)$ & & \\
\hline & & $\mathrm{N}$ & $\begin{array}{l}\text { mean TSCC } \\
\text { score (SD) }\end{array}$ & $\mathrm{N}$ & $\begin{array}{l}\text { mean TSCC } \\
\text { score (SD) }\end{array}$ & $p$ & \\
\hline \multirow[t]{8}{*}{ USSS } & rs3800373 & & & & & $\begin{array}{c}E<0.001 ; G=0.005 \\
G x E=0.004\end{array}$ & 0.260 \\
\hline & AA & 187 & $28.8(19.84)$ & 26 & $48.3(26.77)$ & $\mathrm{E}<0.001^{\#} ; \mathrm{G}=0.004^{\#} ;$ & $0.260^{\#}$ \\
\hline & $A C$ & 136 & $25.8(19.56)$ & 20 & $61.7(37.73)$ & $\mathrm{GxE}=\mathbf{0 . 0 0 1 ^ { \# }}$ & \\
\hline & $\mathrm{CC}$ & 18 & $32.5(18.50)$ & 7 & $71.0(12.78)$ & & \\
\hline & rs1360780 & & & & & $\begin{array}{c}E<0.001 ; G=0.017 \\
G x E=0.032\end{array}$ & 0.251 \\
\hline & $\mathrm{CC}$ & 169 & 27.7 (19.68) & 25 & $48.9(27.13)$ & $\mathrm{E}<0.001^{\#} ; \mathrm{G}=\mathbf{0 . 0 0 5 ^ { \# }}$ & $0.254^{\#}$ \\
\hline & $\mathrm{CT}$ & 146 & $27.3(20.09)$ & 20 & $61.0(34.14)$ & $\mathrm{GxE}=\mathbf{0 . 0 0 7 ^ { \# }}$ & \\
\hline & $\mathrm{TT}$ & 25 & $30.7(17.60)$ & 9 & $65.0(16.33)$ & & \\
\hline
\end{tabular}

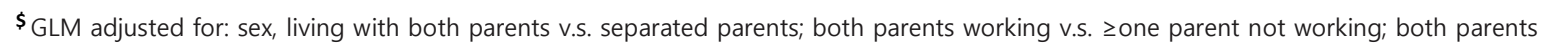
born in Sweden v.s. zone parent born outside Sweden

\# model with 2 levels of genotypes, homozygous for the most common allele vs. carriers of the minor allele

G: genotype main effect; E: environment main effect; GxE: gene-by-environment interaction effect; SDQ: Strength and Difficulties Questionnaire; TSCC: Trauma Symptom Checklist for Children; ALE: adverse life events 
Supplementary Table 1

Demographic characteristics

\begin{tabular}{|c|c|c|c|c|}
\hline & & SESBiC (\%) & USSS (\%) & $\boldsymbol{p}^{\dagger}$ \\
\hline \multicolumn{5}{|l|}{ Sex } \\
\hline & Male & 50.1 & 54.3 & n.s. \\
\hline \multicolumn{5}{|l|}{ Secondary school } \\
\hline & Higher education preparatory programs & & 0 & \\
\hline & Vocational program & & 81 & \\
\hline & Introductory program & & 19 & \\
\hline \multicolumn{5}{|l|}{ Graduate school } \\
\hline & standard program & 100 & & \\
\hline Both parents born in Sweden & & 88.6 & 80.2 & $<0.001$ \\
\hline Living with both biological parents & & 75.5 & 67.3 & $=0.002$ \\
\hline Both parents working & & 81.2 & 61.6 & $<0.001$ \\
\hline
\end{tabular}

Chi square test 


\section{Supplementary Table 2}

\section{Descriptive statistics of FKBP5 SNPs}

\begin{tabular}{|c|c|c|c|c|c|c|}
\hline \multirow{2}{*}{ Cohort } & \multirow[t]{2}{*}{ dbSNP ID } & \multicolumn{2}{|c|}{ Genotype frequencies } & \multirow{2}{*}{$\begin{array}{l}\text { Minor Allele } \\
\text { Frequency }\end{array}$} & \multirow{2}{*}{$\begin{array}{c}\text { HWE } \\
P\end{array}$} & \multirow{2}{*}{$\begin{array}{c}\text { Call rate } \\
\%\end{array}$} \\
\hline & & $\begin{array}{l}\text { Males } \\
\mathrm{N}(\%)\end{array}$ & $\begin{array}{c}\text { Females } \\
\mathrm{N}(\%)\end{array}$ & & & \\
\hline \multirow[t]{8}{*}{ SESBiC } & rs3800373 & & & \multirow{4}{*}{$\begin{array}{c}25 \%(\mathrm{M}) \\
24 \%(\mathrm{~F})\end{array}$} & & 96.7 \\
\hline & AA & $258(49.9)$ & 259 (50.1) & & \multirow{3}{*}{$\begin{array}{c}0.48(\mathrm{M}) \\
0.85(\mathrm{~F})\end{array}$} & \\
\hline & $A C$ & 164 (49.9) & $165(50.2)$ & & & \\
\hline & $\mathrm{CC}$ & $31(55.4)$ & $2544.6)$ & & & \\
\hline & rs1360780 & & & & & 95.4 \\
\hline & CC & $235(48.7)$ & $248(51.3)$ & \multirow{3}{*}{$\begin{array}{c}28 \%(\mathrm{M}) \\
25 \%(\mathrm{~F})\end{array}$} & \multirow{3}{*}{$\begin{array}{c}0.60(\mathrm{M}) \\
0.80(\mathrm{~F})\end{array}$} & \\
\hline & CT & $173(50.6)$ & 169 (49.4) & & & \\
\hline & TT & 36 (57.1) & $27(42.9)$ & & & \\
\hline \multirow[t]{8}{*}{ USSS } & rs3800373 & & & \multirow{4}{*}{$\begin{array}{c}27 \%(\mathrm{M}) \\
29 \%(\mathrm{~F})\end{array}$} & & 95.5 \\
\hline & AA & 110 (51.6) & $103(48.4)$ & & \multirow{3}{*}{$\begin{array}{c}0.12(\mathrm{M}) \\
0.56(\mathrm{~F})\end{array}$} & \\
\hline & $A C$ & 93 (59.6) & $63(40.4)$ & & & \\
\hline & CC & $12(48.0)$ & 13 (52.9) & & & \\
\hline & rs1360780 & & & & & 95.5 \\
\hline & CC & 103 (53.1) & 91 (46.9) & \multirow{3}{*}{$\begin{array}{c}30 \%(\mathrm{M}) \\
25 \%(\mathrm{~F})\end{array}$} & \multirow{3}{*}{$\begin{array}{c}0.44(\mathrm{M}) \\
0.44(\mathrm{~F})\end{array}$} & \\
\hline & CT & $95(57.2)$ & $71(42.8)$ & & & \\
\hline & TT & $17(50.0)$ & $17(50.0)$ & & & \\
\hline
\end{tabular}

F: females; HWE: Hardy-Weinberg Equilibrium; M: males; SNPs: single-nucleotide polymorphisms 
FKBP5, stress and mental health

Supplementary Table 3a

Strength and Difficulties Questionnaire (SDQ) scores by sex in the SESBiC cohort

\begin{tabular}{llcccc} 
SDQ & Sex & N & Mean & SD & $\boldsymbol{p}^{\mathbf{1}}$ \\
\hline TOTAL & Male & 455 & 11 & 6 & 0.044 \\
& Female & 454 & 10.2 & 5.5 & \\
\hline Conduct & Male & 455 & 1.7 & 1.5 & 0.002 \\
& Female & 454 & 1.4 & 1.2 & \\
\hline Emotional & Male & 455 & 1.8 & 1.7 & $<0.001$ \\
& Female & 454 & 2.6 & 1.9 & \\
\hline Hyperactivity / & Male & 455 & 3.8 & 2.1 & $<0.001$ \\
inattention & Female & 454 & 3.1 & 1.9 & \\
\hline Peer problems & Male & 455 & 1.8 & 1.5 & 0.101 \\
& Female & 454 & 1.6 & 1.4 & \\
\hline Pro-social & Male & 455 & 7.7 & 1.7 & $<0.001$ \\
behaviour & Female & 454 & 8.6 & 1.4 & \\
& &
\end{tabular}

TOTAL is the sum of the subscales: Conduct, Emotional, Hyperactivity / inattention and Peer problems : T-test 
Supplementary Table 3b

Trauma Symptom Checklist for Children (TSCC) scores by sex in the USSS cohort

\begin{tabular}{|c|c|c|c|c|c|}
\hline & Sex & $\mathbf{N}$ & Mean & SD & $p^{4}$ \\
\hline \multirow{3}{*}{ TOTAL } & Male & & & & 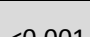 \\
\hline & & 216 & 25,6 & 21,92 & 0.001 \\
\hline & & 182 & 387 & 2338 & \\
\hline \multirow{4}{*}{ ANX } & Male & & & & \\
\hline & & 216 & 3,0 & 3,66 & $<0.001$ \\
\hline & Female & & & & \\
\hline & & 182 & 6,6 & 4,42 & \\
\hline \multirow{3}{*}{ DEP } & Male & & & & 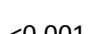 \\
\hline & & 216 & 3,1 & 3,92 & \\
\hline & & 187 & $6 c^{-1}$ & 107 & \\
\hline \multirow{4}{*}{ ANG } & Male & & & & \\
\hline & & 216 & 46 & ח & 0.044 \\
\hline & Female & & & & \\
\hline & & 182 & 5,6 & 4,52 & \\
\hline \multirow{4}{*}{ PTS } & Male & & & & $<0001$ \\
\hline & & 216 & 4,9 & 4,98 & 20.001 \\
\hline & Female & & & & \\
\hline & & 182 & 9,0 & 5,70 & \\
\hline \multirow{3}{*}{ DIS } & Male & & & & $<0001$ \\
\hline & & 216 & 4,8 & 4,64 & \\
\hline & & 182 & 75 & 4.87 & \\
\hline \multirow{4}{*}{ SC } & Male & & & & 0.048 \\
\hline & & 216 & 6,2 & 5,07 & \\
\hline & Female & & & & \\
\hline & & 182 & 5,2 & 4,30 & \\
\hline
\end{tabular}

TOTAL is the sum of the subscales: ANX: anxiety; DEP: depression; ANG: anger; PTS: posttraumatic stress; DIS: dissociation; SC: sexual concerns

: T-test 
Supplementary Table 4

Correlation between total and subscales scores for SDQ and TSCC in adolescents of the SESBiC and USSS cohorts, respectively

\begin{tabular}{|c|c|c|c|c|c|c|c|}
\hline SDQ & & conduct & emotional & $\begin{array}{l}\text { hyperactivity } \\
\text { / inattention }\end{array}$ & $\begin{array}{c}\text { peer } \\
\text { problems }\end{array}$ & $\begin{array}{l}\text { pro-social } \\
\text { behaviour }\end{array}$ & \\
\hline & $\mathrm{N}$ & 909 & 909 & 909 & 909 & 909 & \\
\hline TOTAL SCORE & $r$ & $0.673^{* *}$ & $0.595^{* *}$ & $0.912^{* *}$ & $0.333^{* *}$ & $-0.363^{* *}$ & \\
\hline TSCC & & ANX & DEP & ANG & PTS & DIS & SC \\
\hline & $\mathrm{N}$ & 398 & 398 & 398 & 398 & 398 & 398 \\
\hline TOTAL SCORE & $r$ & $0.850^{* *}$ & $0.873^{* *}$ & $0.835^{* *}$ & $0.893 * *$ & $0.900 * *$ & $0.687^{* *}$ \\
\hline
\end{tabular}

r: Pearson correlation coefficient 
Supplementary table 5

Impact of FKBP5 genotype on psychiatric symptoms in adolescents by TSCC and SDQ and total score and sub-scales in the SESBiC and USSS cohorts, respectively

\begin{tabular}{|c|c|c|c|c|c|}
\hline Cohort & $\begin{array}{l}\text { FKBP5 } \\
\text { genotypes }\end{array}$ & $\mathbf{N}$ & $\begin{array}{c}\text { Psychiatric symptoms } \\
\text { N (SD) }\end{array}$ & $\mathbf{F}$ & $\mathbf{p}$ \\
\hline \multicolumn{6}{|l|}{ SESBiC } \\
\hline \multirow[t]{8}{*}{ SDQ Total } & rs3800373 & & & 0.041 & 0.96 \\
\hline & $\mathrm{AA}$ & 517 & $10.6(5.96)$ & & \\
\hline & $A C$ & 329 & $10.5(5.47)$ & & \\
\hline & $\mathrm{CC}$ & 56 & $10.5(5.67)$ & & \\
\hline & rs1360780 & & & 0.014 & 0.986 \\
\hline & $\mathrm{CC}$ & 483 & $10.6(5.91)$ & & \\
\hline & $\mathrm{CT}$ & 342 & $10.6(5.66)$ & & \\
\hline & TT & 63 & $10.7(5.68)$ & & \\
\hline \multirow[t]{8}{*}{ SDQ Conduct } & rs3800373 & & & 0.028 & 0.972 \\
\hline & AA & 517 & 1.5 (1.39) & & \\
\hline & $A C$ & 329 & $1.5(1.33)$ & & \\
\hline & $\mathrm{CC}$ & 56 & $1.5(1.28)$ & & \\
\hline & rs1360780 & & & 0.081 & 0.922 \\
\hline & $\mathrm{CC}$ & 483 & $1.5(1.38)$ & & \\
\hline & $\mathrm{CT}$ & 342 & $1.6(1.36)$ & & \\
\hline & TT & 63 & $1.5(1.29)$ & & \\
\hline \multirow[t]{8}{*}{ SDQ Emotional } & rs3800373 & & & 1.986 & 0.138 \\
\hline & AA & 517 & $2.3(1.88)$ & & \\
\hline & $A C$ & 329 & $2.1(1.78)$ & & \\
\hline & $\mathrm{CC}$ & 56 & $1.8(1.61)$ & & \\
\hline & rs1360780 & & & 1.339 & 0.263 \\
\hline & $\mathrm{CC}$ & 483 & $2.3(1.84)$ & & \\
\hline & $\mathrm{CT}$ & 342 & $2.2(1.84)$ & & \\
\hline & TT & 63 & $1.9(1.66)$ & & \\
\hline SDQ & rs3800373 & & & & \\
\hline \multirow[t]{8}{*}{ Hyperactivity//inattention } & & & & 0.196 & 0.822 \\
\hline & AA & 517 & $3.4(2.10)$ & & \\
\hline & $A C$ & 329 & $3.4(1.98)$ & & \\
\hline & $\mathrm{CC}$ & 56 & $3.6(2.21)$ & & \\
\hline & rs1360780 & & & 0.358 & 0.699 \\
\hline & $\mathrm{CC}$ & 483 & $3.4(2.09)$ & & \\
\hline & $\mathrm{CT}$ & 342 & $3.4(2.02)$ & & \\
\hline & TT & 63 & $3.7(2.18)$ & & \\
\hline \multirow[t]{8}{*}{ SDQ Peer problems } & rs3800373 & & & 0.24 & 0.787 \\
\hline & $\mathrm{AA}$ & 517 & $1.7(1.48)$ & & \\
\hline & $A C$ & 329 & $1.8(1.42)$ & & \\
\hline & $\mathrm{CC}$ & 56 & $1.6(1.51)$ & & \\
\hline & rs1360780 & & & 0.451 & 0.637 \\
\hline & $\mathrm{CC}$ & 483 & $1.7(1.46)$ & & \\
\hline & $\mathrm{CT}$ & 342 & $1.8(1.43)$ & & \\
\hline & TT & 63 & $1.7(1.61)$ & & \\
\hline \multirow[t]{8}{*}{ SDQ Prosocial } & rs3800373 & & & 0.913 & 0.402 \\
\hline & $\mathrm{AA}$ & 517 & $8.2(1.63)$ & & \\
\hline & $A C$ & 329 & $8.1(1.65)$ & & \\
\hline & $\mathrm{CC}$ & 56 & $8.0(1.65)$ & & \\
\hline & rs1360780 & & & 1.169 & 0.311 \\
\hline & $\mathrm{CC}$ & 483 & $8.2(1.58)$ & & \\
\hline & $\mathrm{CT}$ & 342 & $8.1(1.71)$ & & \\
\hline & TT & 63 & $8.0(1.60)$ & & \\
\hline USSS & rs3800373 & & & 3.331 & 0.037 \\
\hline \multirow[t]{7}{*}{ TSCC Total } & $\mathrm{AA}$ & 213 & $31.1(21.70)$ & & \\
\hline & $A C$ & 156 & $30.4(25.54)$ & & \\
\hline & $\mathrm{CC}$ & 25 & $43.3(24.38)$ & & \\
\hline & rs1360780 & & & 2.313 & 0.1 \\
\hline & $\mathrm{CC}$ & 194 & $30.4(21.90)$ & & \\
\hline & $\mathrm{CT}$ & 166 & $31.4(25.36)$ & & \\
\hline & TT & 34 & $39.8(22.94)$ & & \\
\hline \multirow[t]{3}{*}{ TSCC Anxiety } & rs3800373 & & & 0.815 & 0.443 \\
\hline & $\mathrm{AA}$ & 213 & $4.5(4.25)$ & & \\
\hline & $A C$ & 156 & $4.6(4.65)$ & & \\
\hline
\end{tabular}




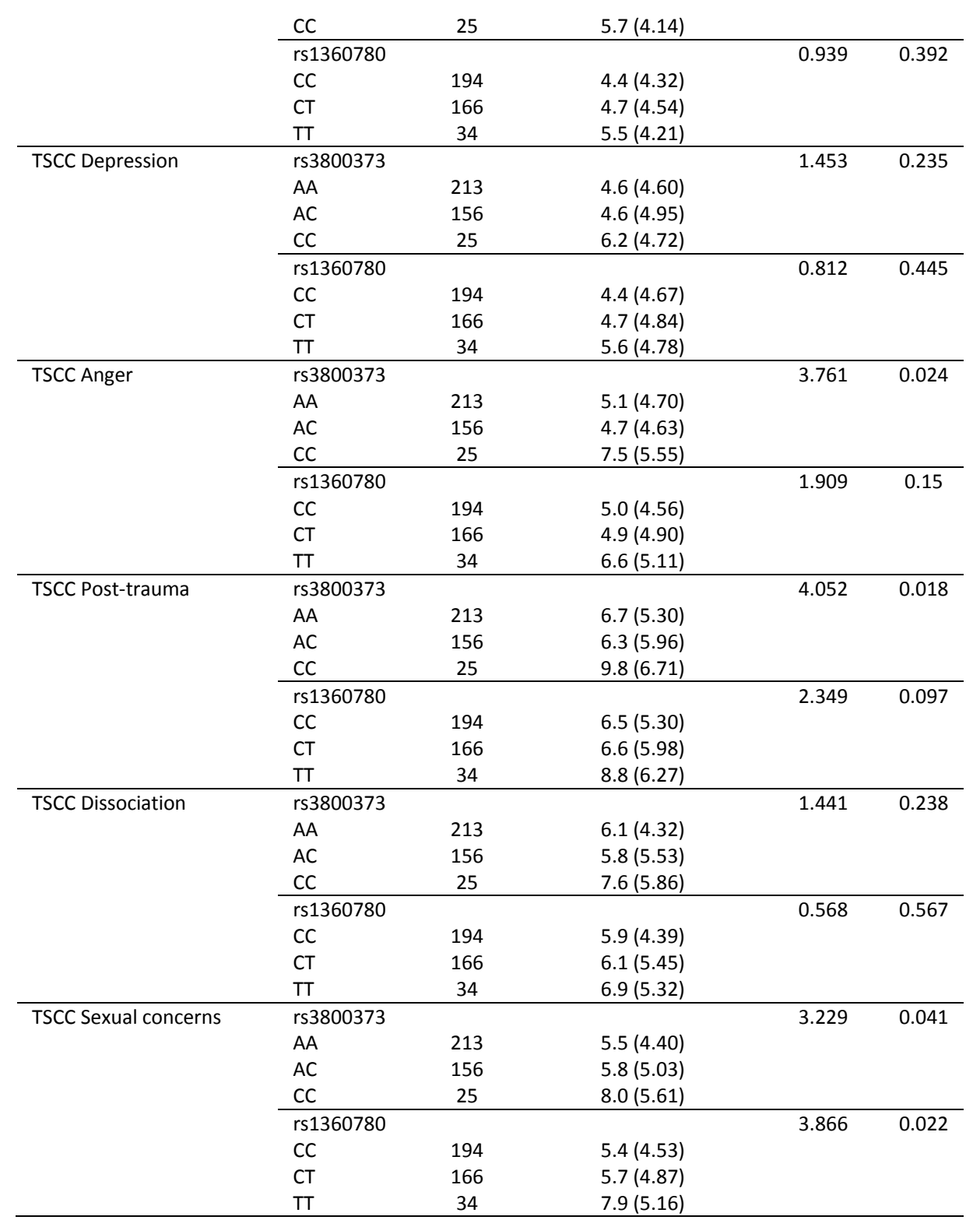


Supplementary tables $6 a$ and $6 b$

Interaction of FKBP5 genotype and level of adverse life events predict psychiatric symptoms in adolescents by by TSCC and SDQ sub-scales in the SESBiC and USSS cohorts, respectively

a) SESBiC cohort

\begin{tabular}{|c|c|c|c|c|c|c|c|}
\hline SDQ & $\begin{array}{c}\text { FKBP5 } \\
\text { Genotypes }\end{array}$ & $\begin{array}{c}\text { Participants } \\
\text { N }\end{array}$ & $\begin{array}{c}\text { ALE }<90 \text { th } \\
\text { percentile } \\
\text { mean SD) }\end{array}$ & $\begin{array}{c}\text { Participants } \\
\text { N }\end{array}$ & $\begin{array}{l}\text { ALE } \geq 90 \text { th } \\
\text { precentile } \\
\text { mean (SD) }\end{array}$ & $p^{5}$ & $\mathbf{R}^{2 \#}$ \\
\hline \multirow[t]{8}{*}{ Conduct } & rs3800373 & & & & & $E=0.173 ; G=0.663 ; G X E=0.519$ & 0.033 \\
\hline & AA & 449 & $1.5(1.40)$ & 68 & $1.7(1.27)$ & & \\
\hline & AC & 272 & $1.4(1.29)$ & 57 & $2.0(1.41)$ & $E=0.041^{\#} ; G=0.376^{\#} ; G X E=0.235^{\#}$ & $0.035^{5}$ \\
\hline & $\mathrm{CC}$ & 52 & $1.4(1.28)$ & 4 & $2.0(1.41)$ & & \\
\hline & rs1360780 & & & & & $E=0.091 ; G=0.541 ; G X E=0.514$ & 0.033 \\
\hline & CC & 422 & $1.5(1.39)$ & 61 & $1.7(1.32)$ & & \\
\hline & CT & 281 & $1.5(1.34)$ & 61 & $2.0(1.38)$ & $E=0.073^{\#} ; G=0.315^{\#} ; G X E=0.279^{\#}$ & $0.033^{\#}$ \\
\hline & $\mathrm{TT}$ & 58 & $1.5(1.29)$ & 5 & $2.2(1.30)$ & & \\
\hline \multirow[t]{8}{*}{ Emotional } & rs3800373 & & & & & $E=0.198 ; G=0.666 ; G X E=0.856$ & 0.057 \\
\hline & $\mathrm{AA}$ & 449 & $2.2(1.84)$ & 68 & $2.6(2.06)$ & & \\
\hline & AC & 272 & $2.0(1.76)$ & 57 & $2.5(1.84)$ & $E=0.009^{\#} ; G=0.444^{\#} ; G X E=0.562^{\# 2}$ & $0.057^{*}$ \\
\hline & $\mathrm{CC}$ & 52 & $1.8(1.59)$ & 4 & $2.3(2.06)$ & & \\
\hline & rs1360780 & & & & & $E=0.113 ; G=0.931 ; G X E=0.761$ & 0.057 \\
\hline & CC & 422 & $2.2(1.81)$ & 61 & $2.5(2.09)$ & & \\
\hline & CT & 281 & $2.1(1.84)$ & 61 & $2.5(1.84)$ & $E=0.016^{\#} ; G=0.928^{\#} ; G X E=0.427^{\#}$ & $0.056^{\#}$ \\
\hline & $\mathrm{TT}$ & 58 & $1.8(1.64)$ & 5 & $2.6(1.95)$ & & \\
\hline \multirow{8}{*}{$\begin{array}{l}\text { Hyperactivity } \\
\text { /inattention }\end{array}$} & rs3800373 & & & & & $E=0.010 ; G=0.083 ; G X E=0.019$ & 0.046 \\
\hline & AA & 449 & $3.4(2.12)$ & 68 & $3.6(1.94)$ & & \\
\hline & AC & 272 & $3.2(1.95)$ & 57 & $4.5(180)$ & $\mathrm{E}=0.003^{\#} ; \mathrm{G}=0.040^{\#} ; \mathrm{GXE}=0.008^{\#}$ & 0.045 \\
\hline & $\mathrm{CC}$ & 52 & $3.5(2.20)$ & 4 & $5.03(1.71)$ & & \\
\hline & rs1360780 & & & & & $E=\mathbf{0 . 0 1 6} ; G=0.277 ; G X E=0.229$ & 0.040 \\
\hline & $\mathrm{CC}$ & 422 & $3.4(2.11)$ & 61 & 3.4 & & \\
\hline & CT & 281 & $3.3(2.01)$ & 61 & $\begin{array}{c}(2.114) \\
3.3(2.01)\end{array}$ & $E=0.011^{\#} ; G=0.268^{\#} ; G X E=0.145^{\#}$ & $0.039^{\#}$ \\
\hline & TT & 58 & $3.5(2.19)$ & 5 & $5.03(1.58)$ & & \\
\hline \multirow{8}{*}{$\begin{array}{l}\text { Peer } \\
\text { problems }\end{array}$} & rs3800373 & & & & & $E=0.404 ; G=0.808 ; G X E=0.600$ & 0.019 \\
\hline & AA & 449 & $1.7(1.44)$ & 68 & $1.6(1.43)$ & & \\
\hline & AC & 272 & $1.7(1.39)$ & 57 & $1.7(1.40)$ & $E=0.037^{\#} ; G=0.566^{\#} ; G X E=0.339^{\#}$ & $0.018^{*}$ \\
\hline & $\mathrm{CC}$ & 52 & $1.6(1.52)$ & 4 & $1.7(1.58)$ & & \\
\hline & rs1360780 & & & & & $E=0.089 ; G=0.820 ; ; G X E=0.665$ & 0.018 \\
\hline & CC & 422 & $1.6(1.43)$ & 61 & $2.1(1.62)$ & & \\
\hline & СT & 281 & $1.7(1.41)$ & 61 & $2.0(1.56)$ & $E=0.040^{\#} ; G=0.815^{\#} ; G X E=0.642^{\#}$ & $0.018^{\#}$ \\
\hline & TT & 58 & $1.7(1.60)$ & 5 & $2.4(1.95)$ & & \\
\hline \multirow{8}{*}{$\begin{array}{l}\text { Prosocial } \\
\text { behaviour }\end{array}$} & rs3800373 & & & & & $\mathrm{E}=\mathbf{0 . 0 3 9 ;} \mathrm{G}=0.081 ; \mathrm{GXE}=0.194$ & 0.091 \\
\hline & AA & 449 & $8.2(1.63)$ & 68 & $8.0(1.62)$ & & \\
\hline & AC & 272 & $8.2(1.57)$ & 57 & $7.5(1.89)$ & $E=0.073^{\#} ; G=0.053^{\#} ; G X E=0.138^{\#}$ & $0.090^{*}$ \\
\hline & $\mathrm{CC}$ & 52 & $8.1(1.61)$ & 4 & $6.8(0.96)$ & & \\
\hline & rs1360780 & & & & & $E=0.076 ; G=0.066 ; G X E=0.173$ & 0.087 \\
\hline & CC & 422 & $8.2(1.58)$ & 61 & $8.1(1.61)$ & & \\
\hline & CT & 281 & $8.2(1.66)$ & 61 & $7.5(1.85)$ & $E=0.125^{\#} ; G=0.027^{*} ; G X E=0.080^{\#}$ & $0.086^{*}$ \\
\hline & $\mathrm{TT}$ & 58 & $8.2(1.61)$ & 5 & $7.2(1.30)$ & & \\
\hline
\end{tabular}

\$ GLM adjusted for: sex, living with both parents v.s. separated parents; both parents working v.s. $\geq$ one parent not working; both parents born in Sweden v.s. $\geq$ one parent born outside Sweden.

\# model with 2 levels of genotypes, homozygous for the most common allele vs. carriers of the minor allele

E: environment main effect; GxE: gene-by-environment interaction effect; SDQ: Strength and Difficulties Questionnaire; ALE: adverse life events 
b) USSS cohort

\begin{tabular}{|c|c|c|c|c|c|c|c|}
\hline TSCC & $\begin{array}{c}\text { FKBP5 } \\
\text { Genotypes }\end{array}$ & $\begin{array}{c}\text { Participants } \\
\text { N }\end{array}$ & $\begin{array}{l}\text { ALE <90th } \\
\text { percentile } \\
\text { mean (SD) }\end{array}$ & $\begin{array}{c}\text { Participants } \\
\text { N }\end{array}$ & $\begin{array}{l}\text { ALE } \geq 90 \text { th } \\
\text { precentile } \\
\text { mean (SD) }\end{array}$ & $p^{\$}$ & $\mathrm{R}^{2 \#}$ \\
\hline \multirow[t]{8}{*}{ Anxiety } & rs3800373 & & & & & $E<0.001 ; G=0.034 ; G X E=0.025$ & 0.283 \\
\hline & AA & 187 & $4.2(3.92)$ & 26 & $7.2(5.50)$ & & \\
\hline & $A C$ & 136 & $3.9(3.70)$ & 20 & $9.8(6.82)$ & $\mathrm{E}=<0.001^{\#} ; \mathrm{G}=0.011^{\#} ; \mathrm{GXE}=0.008^{\#}$ & $0.270^{\#}$ \\
\hline & $\mathrm{CC}$ & 18 & $4.7(3.60)$ & 7 & $8.4(4.47)$ & & \\
\hline & rs1360780 & & & & & $E<0.001 ; G=0.047 ; G X E=0.075$ & 0.278 \\
\hline & $\mathrm{CC}$ & 169 & $4.0(3.95)$ & 25 & $7.3(5.62)$ & & \\
\hline & $\mathrm{CT}$ & 146 & $4.0(3.71)$ & 20 & $9.5(6.82)$ & $\mathrm{E}=<0.001^{\#} ; \mathrm{G}=0.013^{\#} ; \mathrm{GXE}=0.023^{\#}$ & $0.265^{\#}$ \\
\hline & $\mathrm{TT}$ & 25 & $4.3(3.58)$ & 9 & $8.9(4.17)$ & & \\
\hline \multirow[t]{8}{*}{ Depression } & rs3800373 & & & & & $E<0.001 ; G=0.001 ; G X E<0.001$ & 0.280 \\
\hline & AA & 187 & $4.3(4.35)$ & 26 & $6.5(5.87)$ & & \\
\hline & $A C$ & 136 & $3.7(3.77)$ & 20 & $10.5(7.58)$ & $\mathrm{E}<0.001^{\#} ; \mathrm{G}<0.001^{\#} ; \mathrm{GXE}<0.001^{\#}$ & $0.266^{\#}$ \\
\hline & $\mathrm{CC}$ & 18 & 4.4 (3.99) & 7 & $10.9(3.08)$ & & \\
\hline & rs1360780 & & & & & $E<0.001 ; G=0.003 ; G X E<0.001$ & 0.275 \\
\hline & $\mathrm{CC}$ & 169 & $4.1(4.38)$ & 25 & $6.6(5.97)$ & & \\
\hline & $\mathrm{CT}$ & 146 & $4.0(3.78)$ & 20 & $10.1(7.71)$ & $\mathrm{E}<0.001^{\#} ; \mathrm{G}<0.001^{\#} ; \mathrm{GXE}<0.001^{\#}$ & $0.260^{\#}$ \\
\hline & TT & 25 & $3.6(3.82)$ & 9 & $10.9(2.67)$ & & \\
\hline \multirow[t]{8}{*}{ Anger } & rs3800373 & & & & & $E<0.001 ; G=0.039 ; G X E=0.038$ & 0.185 \\
\hline & AA & 187 & $4,7(4.43)$ & 26 & $8.3(5.44)$ & & \\
\hline & $A C$ & 136 & 3.9 (3.79) & 20 & $10.1(6.16)$ & 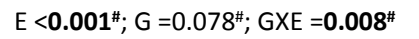 & 0.162 \\
\hline & $\mathrm{CC}$ & 18 & $5.4(4.02)$ & 7 & $12.9(5.52)$ & & \\
\hline & rs1360780 & & & & & $\mathrm{E}<0.001 ; \mathrm{G}=0.191 ; \mathrm{GXE}=0.258$ & 0.169 \\
\hline & $\mathrm{CC}$ & 169 & $4.4(4.19)$ & 25 & $8.5(5.39)$ & & \\
\hline & $\mathrm{CT}$ & 146 & $4.3(4.28)$ & 20 & $9.9(6.32)$ & $\mathrm{E}<0.001^{\#} ; \mathrm{G}=0.102^{\#} ; \mathrm{GXE}=0.084^{\#}$ & $0.153^{\#}$ \\
\hline & $\mathrm{TT}$ & 25 & $5.0(3.73)$ & 9 & $11.2(5.78)$ & & \\
\hline \multirow[t]{8}{*}{ Post-trauma } & rs3800373 & & & & & $E<0.001 ; G=0.007 ; G X E=0.011$ & 0.319 \\
\hline & AA & 187 & $6.0(4.94)$ & 26 & $11.5(5.39)$ & & \\
\hline & $A C$ & 136 & $5.3(5.16)$ & 20 & $12.8(7.09)$ & 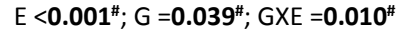 & $0.295^{\#}$ \\
\hline & $\mathrm{CC}$ & 18 & $6.7(4.86)$ & 7 & $17.6(3.78)$ & & \\
\hline & rs1360780 & & & & & $E<0.001 ; G=0.045 ; G X E=0.072$ & 0.311 \\
\hline & $\mathrm{CC}$ & 169 & $5.8(4.85)$ & 25 & $11.6(5.48)$ & & \\
\hline & $\mathrm{CT}$ & 146 & $5.8(5.31)$ & 20 & $12.8(7.06)$ & 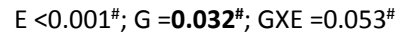 & 0.294 \\
\hline & $\mathrm{TT}$ & 25 & $6.3(4.62)$ & 9 & $15.7(5.03)$ & & \\
\hline \multirow[t]{8}{*}{ Dissociation } & rs3800373 & & & & & $E<0.001 ; G=0.020 ; G X E=0.001$ & 0.266 \\
\hline & AA & 187 & $5.6(3.96)$ & 26 & $9.4(5.34)$ & & \\
\hline & $A C$ & 136 & $4.8(4.31)$ & 20 & $12.6(7.87)$ & $E<0.001^{\#} ; G=0.005^{\#} ; G X E<0.001^{\#}$ & $0.251^{\#}$ \\
\hline & $\mathrm{CC}$ & 18 & $5.1(4.30)$ & 7 & $14.0(4.32)$ & & \\
\hline & rs1360780 & & & & & $E<0.001 ; G=0.023 ; G X E=0.008$ & 0.259 \\
\hline & $\mathrm{CC}$ & 169 & $5.4(3.96)$ & 25 & $9.4(5.44)$ & & \\
\hline & $\mathrm{CT}$ & 146 & $5.2(4.37)$ & 20 & $12.6(7.87)$ & $E<0.001^{\#} ; G=0.005^{\#} ; G X E=0.003^{\#}$ & $0.244^{\#}$ \\
\hline & TT & 25 & $4.8(3.86)$ & 9 & $12.6(4.72)$ & & \\
\hline \multirow{8}{*}{$\begin{array}{l}\text { Sexual } \\
\text { concerns }\end{array}$} & rs3800373 & & & & & $E<0.001 ; G=0.060 ; G X E=0.376$ & 0.093 \\
\hline & $A A$ & 187 & $5.2(4.19)$ & 26 & $7.4(5.43)$ & & \\
\hline & $A C$ & 136 & $5.3(4.26)$ & 20 & $9.2(7.95)$ & $\mathrm{E}<0.001^{\#} ; \mathrm{G}=0.068^{\#} ; \mathrm{GXE}=0.123^{\#}$ & $0.069^{\#}$ \\
\hline & $\mathrm{CC}$ & 18 & $7.1(5.62)$ & 7 & $10.3(5.25)$ & & \\
\hline & rs1360780 & & & & & $E<0.001 ; G=0.087 ; G X E=0.266$ & 0.094 \\
\hline & $\mathrm{CC}$ & 169 & $5.1(4.30)$ & 25 & $7.4(5.54)$ & & \\
\hline & $\mathrm{CT}$ & 146 & $5.2(4.09)$ & 20 & $9.3(7.91)$ & $E<0.001^{\#} ; G=0.072^{\#} ; G X E=0.219^{\#}$ & $0.065^{\#}$ \\
\hline & $\mathrm{TT}$ & 25 & $7.5(5.15)$ & 9 & $8.89(5.35)$ & & \\
\hline
\end{tabular}

\$ GLM adjusted for: sex, living with both parents v.s. separated parents; both parents working v.s. $\geq$ one parent not working; both parents born in Sweden v.s. $\geq$ one parent born outside Sweden.

\# model with 3 levels of SNPs and with 2 levels

E: environment main effect; GxE: gene-by-environment interaction effect; TSCC: Trauma Symptom Checklist for Children; ALE: adverse life events 
Supplementary Table 7

FKBP5 rs3800373 and rs1360780 genotype-dependent correlation effects between adverse life events and psychiatric symptoms assessed with SDQ and TSCC in adolescents of the SESBiC and USSS cohorts, respectively

\begin{tabular}{|c|c|c|c|c|c|c|}
\hline & \multicolumn{3}{|c|}{ rs3800373 } & \multicolumn{3}{|c|}{ rs1360780 } \\
\hline & AA & AC & $\mathrm{CC}$ & $\mathrm{CC}$ & CT & TT \\
\hline \multicolumn{7}{|l|}{ SESBiC } \\
\hline $\mathrm{N}$ & 517 & 329 & 56 & 483 & 342 & 63 \\
\hline$r$ & $0.125^{* *}$ & $0.314^{* * *}$ & 0.052 & $0.128 * *$ & $0.273^{* * *}$ & 0.083 \\
\hline$Z$ value for difference & $\mathrm{AA} / \mathrm{AC}=2.82^{\mathrm{b}}$ & $\mathrm{AC} / \mathrm{CC}=1.86$ & $\mathrm{AA} / \mathrm{CC}=0.51$ & $C C / C T=2.14^{a}$ & $\mathrm{CT} / \mathrm{TT}=1.42$ & $\mathrm{CC} / \mathrm{TT}=0.33$ \\
\hline \multicolumn{7}{|l|}{ USSS } \\
\hline $\mathrm{N}$ & 213 & 156 & 25 & 194 & 166 & 34 \\
\hline$r$ & $0.392 * * *$ & $0.542 * * *$ & $0.888 * * *$ & $0.391 * * *$ & $0.593 * * *$ & $0.841 * * *$ \\
\hline$Z$ value for difference & $\mathrm{AA} / \mathrm{AC}=1.81$ & $\mathrm{AC} / \mathrm{CC}=3.53^{\mathrm{b}}$ & $\mathrm{AA} / \mathrm{CC}=4.45^{\mathrm{b}}$ & $\mathrm{CC} / \mathrm{CT}=1.78$ & $\mathrm{CT} / \mathrm{TT}=3.17^{\mathrm{b}}$ & $\mathrm{CC} / \mathrm{TT}=4.19^{\mathrm{b}}$ \\
\hline
\end{tabular}

r: Pearson correlation coefficient, ${ }^{*}=p<0.05,{ }^{* *}=p<0.01,{ }^{* *}=p<0.001$

a $p<0.05$, b $p<0.01$ 


\section{Supplementary Table 8}

Diplotypes of FKBP5 SNPs

\begin{tabular}{llcc} 
Cohort & rs3800373- rs1360780 diplotypes & \multicolumn{2}{c}{ Diplotype frequencies } \\
& & Males & Females \\
& $\mathrm{N}(\%)$ & $\mathrm{N}(\%)$ \\
\hline SESBiC & & & \\
& Homozygous for major allele at both loci & $229(48.4)$ & $244(51.6)$ \\
& All other combinations & $183(51.7)$ & $171(48.3)$ \\
& Homozygous for minor allele at both loci & $30(55.6)$ & $24(44.4)$ \\
\hline USSS & & & \\
& Homozygous for major allele at both loci & $100(52.4)$ & $91(47.6)$ \\
& All other combinations & $102(58.6)$ & $72(41.4)$ \\
& Homozygous for minor allele at both loci & $12(48.0)$ & $13(52.0)$ \\
\hline
\end{tabular}


Supplementary Table 9

Interaction effect of FKBP5 diplotypes and adverse life events associated with psychiatric symptoms (assessed with SDQ and TSCC) in adolescents of the SESBiC and USSS cohorts, respectively

\begin{tabular}{|c|c|c|c|c|c|c|c|}
\hline $\begin{array}{l}\text { Total } \\
\text { score }\end{array}$ & $\begin{array}{l}\text { FKBP5 } \\
\text { rs3800373 - rs1360780 } \\
\text { diplotypes }\end{array}$ & $\begin{array}{c}\text { Participants } \\
\text { N }\end{array}$ & $\begin{array}{l}\text { ALE }<90 \text { th } \\
\text { percentile }\end{array}$ & $\begin{array}{c}\text { Participants } \\
\text { N }\end{array}$ & $\begin{array}{l}\text { ALE } \geq 90 \text { th } \\
\text { percentile }\end{array}$ & $p^{\$}$ & $\mathbf{R}^{2}$ \\
\hline \multirow[t]{4}{*}{ SDQ } & \multirow{4}{*}{$\begin{array}{l}\text { Homozygous for major } \\
\text { allele at both loci } \\
\text { All other combinations } \\
\text { Homozygous for minor } \\
\text { allele at both loci }\end{array}$} & & $\begin{array}{l}\text { mean SDQ } \\
\text { score (SD) }\end{array}$ & & $\begin{array}{l}\text { mean SDQ } \\
\text { score (SD) }\end{array}$ & \multirow{4}{*}{$\begin{array}{c}E<0.017 ; G=0.478 \\
G x E=0.275\end{array}$} & \multirow{4}{*}{0.014} \\
\hline & & 413 & $10.4(5.94)$ & 60 & $11.6(5.75)$ & & \\
\hline & & 291 & $10.1(5.61)$ & 63 & $12.9(5.21)$ & & \\
\hline & & 50 & $10.2(5.63)$ & 4 & $14.8(6.02)$ & & \\
\hline \multirow[t]{4}{*}{ TSCC } & & & $\begin{array}{l}\text { mean TSCC } \\
\text { score (SD) }\end{array}$ & & $\begin{array}{l}\text { mean TSCC } \\
\text { score (SD) }\end{array}$ & \multirow{4}{*}{$\begin{array}{c}E<0.001 ; G=0.007 \\
G \times E=0.021\end{array}$} & \multirow{4}{*}{0.255} \\
\hline & $\begin{array}{l}\text { Homozygous for major } \\
\text { allele at both loci }\end{array}$ & 166 & $27.9(19.66)$ & 25 & $48.9(27.13)$ & & \\
\hline & All other combinations & 153 & $27.0(20.03)$ & 21 & $60.3(37.31)$ & & \\
\hline & $\begin{array}{l}\text { Homozygous for minor } \\
\text { allele at both loci }\end{array}$ & 18 & $32.5(19.75)$ & 7 & $71.0(12.78)$ & & \\
\hline
\end{tabular}

\$ GLM adjusted for: sex, living with both parents v.s. separated parents; both parents working v.s. $\geq$ one parent not working; both parents born in Sweden v.s. $\geq$ one parent born outside Sweden. ALE: adverse life events 
Supplementary Figure

Relation of adverse life events (<90th percentile vs. $\geq 90$ th percentile) to estimated marginal means of psychiatric symptoms in adolescents (SDQ in the SESBiC cohort and TSCC in the USSS cohort) by FKBP5 diplotypes

SESBiC cohort

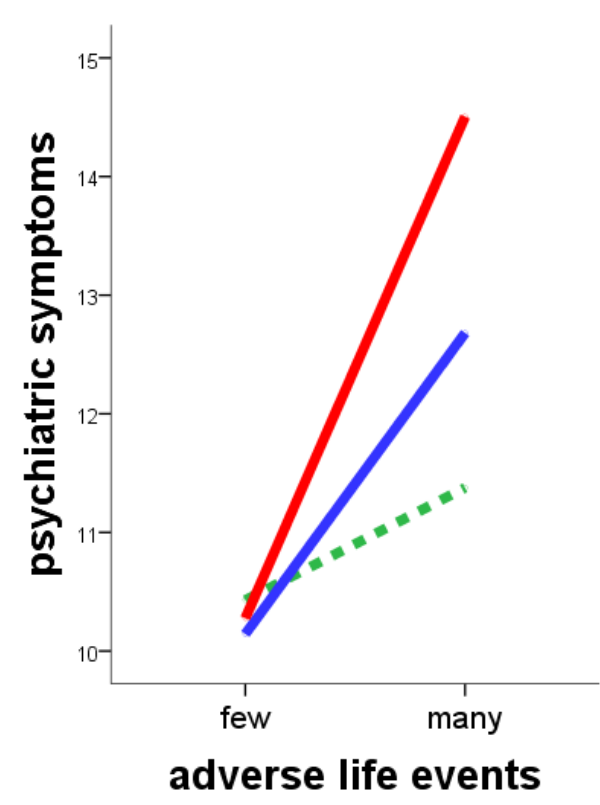

GXE: $p=0.275$
USSS cohort

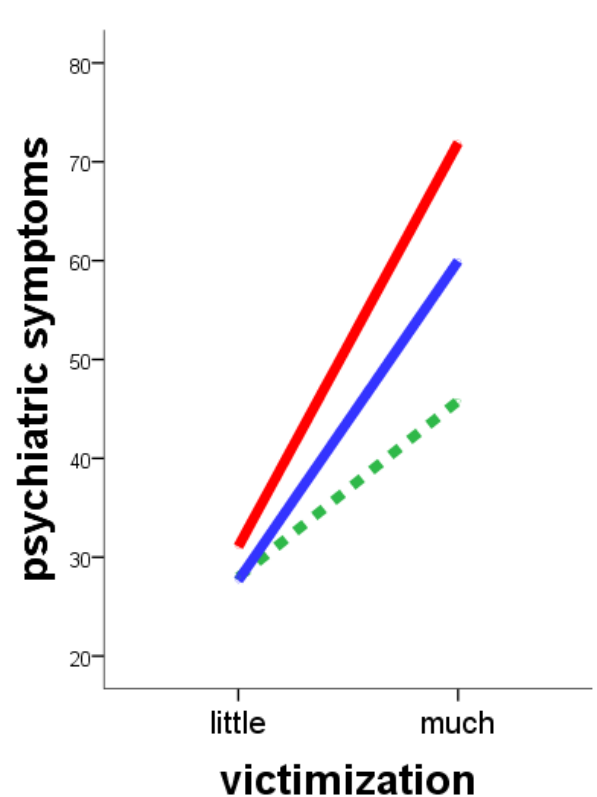

GXE: $p=0.021$

SDQ: Strength and Difficulties Questionnaire; TSCC: Trauma Symptom Checklist for Children

GxE: gene-by-environment interaction effect based on GLM model adjusted for: sex, living with both parents v.s. separated parents, both parents working v.s. than one parent not working, both parents born in Sweden v.s. more than one parent born outside Sweden

I. Homozygous for major allele at both loci

All other combinations

Homozygous for minor allele at both loci 